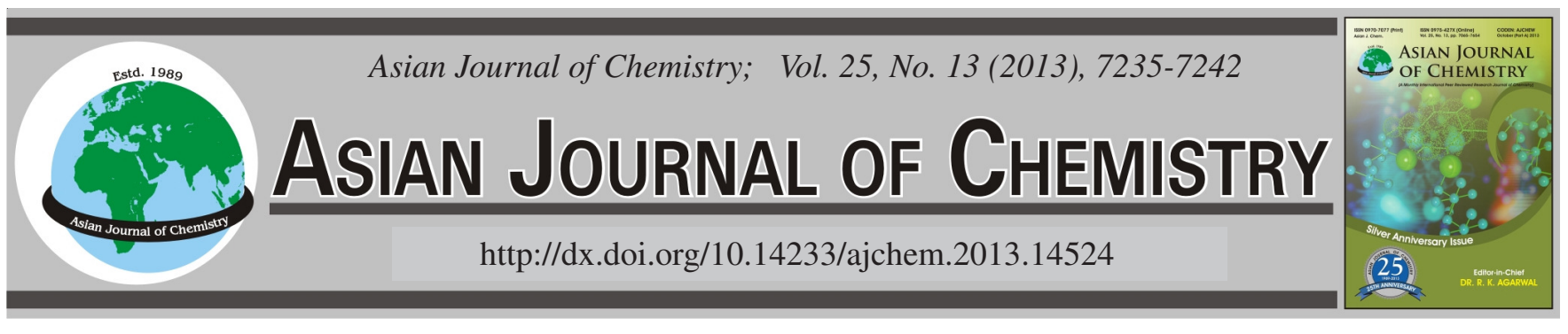

\title{
Theoretical Investigations of Interaction Between Boron Group Elements and Noble Gases with Charged Reactants in $\mathrm{CO}_{2}$ Photoreduction with $\mathrm{H}_{2} \mathrm{O}$ System
}

\author{
Dongmei Luo ${ }^{1, *}$, Wei $\mathrm{Kan}^{2}$, Ning Zhang ${ }^{3}$, Wenmin XiaO ${ }^{1}$ and XiaOfei Zhang ${ }^{1}$
}

${ }^{1}$ College of Chemistry and Chemical Engineering, Chifeng University, Chifeng 024000, P.R. China

${ }^{2}$ Department of Chemistry and Chemical Engineering, Qiqihar University, Qiqihar 161006, P.R. China

*Corresponding author: Tel: +86 476 8300368, E-mail: luodongmei1976@163.com

(Received: 5 September 2012;

Accepted: 19 June 2013)

AJC-13680

\begin{abstract}
The interaction between boron group elements and noble gases with charged reactants has been investigated theoretically in the synthesis of methanol by photoreduction of $\mathrm{CO}_{2}$ with $\mathrm{H}_{2} \mathrm{O}$. The different effects of boron group elements and noble gases have been calculated at MP2 level. Noble gas atoms interacted with $\mathrm{H}_{2} \mathrm{O}^{+}$and the third main-group elements interacted with $\mathrm{CO}_{2}{ }^{-}$. Our results revealed that boron group elements might maintain the structure of $\mathrm{CO}_{2}{ }^{--}$like $\mathrm{CO}_{3}{ }^{2-}$, which is convenient for appropriate radicals reacting with $\mathrm{CO}_{2}{ }^{--}$to form the aim product or its precursor, therefore the electron-defect atom is advantageous to the reaction herein. It is interesting that the rare gas elements tend to inert $\mathrm{H}_{2} \mathrm{O}^{+}$to the structure of $\mathrm{H}_{2} \mathrm{O}$. The excited state parameters showed that $\mathrm{Ga}, \mathrm{Kr}$ and $\mathrm{Xe}$ are beneficial to the photoreduction of $\mathrm{CO}_{2}$ with $\mathrm{H}_{2} \mathrm{O}$.
\end{abstract}

Key Words: Boron group elements, Noble gases, $\mathrm{H}_{2} \mathrm{O}^{+}, \mathrm{CO}_{2}{ }^{--}$, MP2.

\section{INTRODUCTION}

The exhaustive research of highly efficient and selective photocatalytic systems that work without any loss of energy in the utilization of solar energy through chemical storage is of vital interest. Especially, the efficient photocatalytic reduction of $\mathrm{CO}_{2}$ with $\mathrm{H}_{2} \mathrm{O}$ is one of the most desirable and challenging goals in the research of environmentally friendly catalysts $^{1-4}$. From the research results and literature reports, a reaction scheme is proposed for photocatalytic reduction of carbon dioxide with water as follows:

$$
\mathrm{TiO}_{2} \stackrel{\text { hv }}{\longrightarrow} \mathrm{e}_{\mathrm{cb}}{ }^{-}\left(\mathrm{TiO}_{2}\right)+\mathrm{h}^{+}{ }_{\mathrm{vb}}\left(\mathrm{TiO}_{2}\right)
$$

Incident photons are absorbed by $\mathrm{TiO}_{2}$ and photoexcited electrons $\left(\mathrm{e}^{-}\right)$and positive holes $\left(\mathrm{h}^{+}\right)$are produced in the catalyst by charge transfer to the excited state of $\left(\mathrm{Ti}^{3+}-\mathrm{O}^{-}\right)^{*}$. Furthermore, the photoexcited electrons and holes in the lattice are separated and trapped by appropriate sites of $\mathrm{TiO}_{2}$ to avoid recombination. The interaction of $\mathrm{CO}_{2}$ molecules with the excited state of $\left(\mathrm{Ti}^{3+}-\mathrm{O}^{-}\right)^{*}$ leads to the formation of radicals ${ }^{5}$. The photooxidation of water, the solvent, leads to the formation of hydroxyl radicals $\mathrm{OH}^{\bullet}$ and $\mathrm{H}^{+}$through water oxidation by the valance band holes produced due to laser irradiation of the semiconductor (SC) catalyst ${ }^{6-11}$.

$$
\begin{gathered}
\mathrm{SC} \stackrel{\mathbf{h v}<\mathrm{Eg}_{\mathrm{g}}}{\longrightarrow} \mathrm{SC}\left(\mathrm{h}_{\mathrm{vb}}^{+}+\mathrm{e}_{\mathrm{cb}}^{-}\right) \\
\mathrm{H}_{2} \mathrm{O}+\mathrm{h}_{\mathrm{vb}}^{+} \rightarrow \mathrm{H}_{2} \mathrm{O}^{+} \rightarrow \mathrm{OH}^{\bullet}+\mathrm{H}^{+}
\end{gathered}
$$

The hydroxyl radicals generate oxygen while $\mathrm{H}^{+}$ions form hydrogen by capturing conduction band electrons ${ }^{12}$.

There is a difficulty that the photo-induced electron and the photo-induced hole are very apt to recombine, therefore many methods are being developing to prevent it from recombining, such as adding the hole sacrificial reagent, or modifying photocatalysts ${ }^{13}$ etc. Furthermore, the interaction between $\mathrm{H}_{2} \mathrm{O}^{+}$ and noble gases for their full of electrons in the valence shell, as well as $\mathrm{CO}_{2}{ }^{--}$and boron group elements for their electron deficient in the valence shell which might affect the reaction trend if any of them exists in the photocatalytic reaction system. The importance of the optimization of complexes by boron group elements and noble gases with charged reactants has not been previously ascertained.

The interaction between $\mathrm{CO}_{2}{ }^{--}$and boron group elements and $\mathrm{H}_{2} \mathrm{O}^{+}$and the rare gas elements were represented to be complexes. The complexes formed by $\mathrm{CO}_{2}{ }^{--}$with boron group elements was expressed as $\mathrm{CO}_{2}{ }^{--}-\mathrm{M}(\mathrm{M}=\mathrm{B}, \mathrm{Al}, \mathrm{Ga}$, In and $\mathrm{Tl})$ and which formed by $\mathrm{H}_{2} \mathrm{O}^{+}$with the rare gas elements was expressed as $\mathrm{H}_{2} \mathrm{O}^{+}-\mathrm{M}(\mathrm{He}, \mathrm{Ne}, \mathrm{Ar}, \mathrm{Kr}$ and $\mathrm{Xe}$ ). The quantum chemistry of all of them in this work has not been reported yet to the best of our knowledge.

\section{COMPUTATIONAL DETAILS}

The ground state geometry optimization, frequencies and thermochemistry and excited state structures, maximum 
adsorption wavelength of $\mathrm{CO}_{2}{ }^{--}-\mathrm{M}(\mathrm{M}=\mathrm{B}, \mathrm{Al}, \mathrm{Ga}$, In and $\mathrm{Tl})$ and $\mathrm{H}_{2} \mathrm{O}^{+}-\mathrm{M}(\mathrm{He}, \mathrm{Ne}, \mathrm{Ar}, \mathrm{Kr}$ and $\mathrm{Xe}$ ) have been calculated and all results were obtained with the Second-order MollerPlesset Perturbation Theory ${ }^{14-17}$ MP2 with different basis sets and among the basis sets LANL2DZ for Xe, In and $\mathrm{Tl}^{18}, 6-311 \mathrm{G}^{*}$ for $\mathrm{O}, \mathrm{H}, \mathrm{B}, \mathrm{Ne}$ and $\mathrm{C}^{19}, 6-311 \mathrm{G}^{*}$ for $\mathrm{Al}$ and $\mathrm{Ar}^{20}, 6-311 \mathrm{G}^{*}$ for $\mathrm{Ga}$ and $\mathrm{Kr}^{21}$ were chosen as the optimal ones according to the data from calculations of the complexes. All calculations were carried out using GAUSSIAN 09 program package ${ }^{22}$. The optimization geometric structure of the complexes was shown in Figs. 1 and 2.

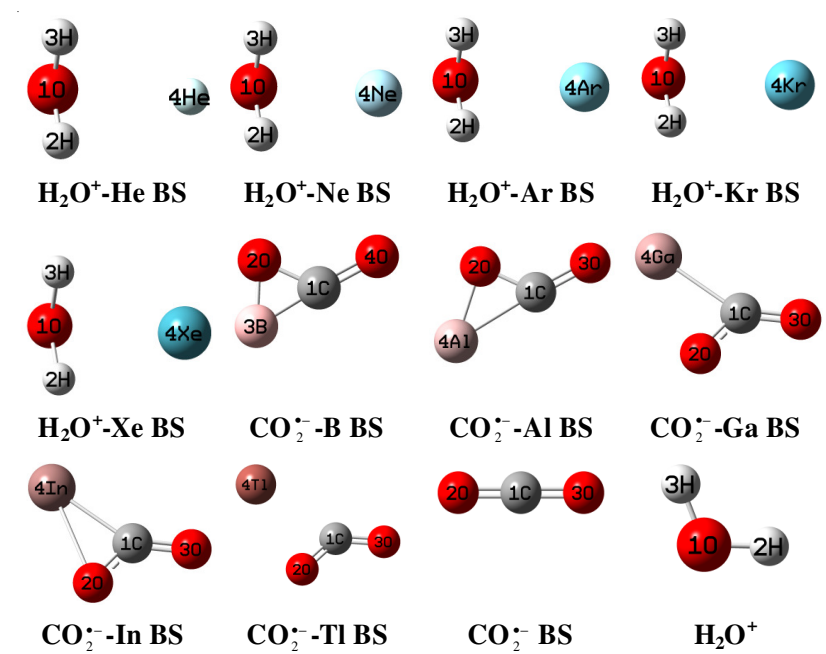

Fig. 1. Optimized ground state structure of $\mathrm{H}_{2} \mathrm{O}^{+}-\mathrm{M}(\mathrm{He}, \mathrm{Ne}, \mathrm{Ar}, \mathrm{Kr}$ and $\mathrm{Xe})$ and $\mathrm{CO}_{2}{ }^{--}-\mathrm{M}(\mathrm{B}, \mathrm{Al}, \mathrm{Ga}$, In and $\mathrm{Tl})$

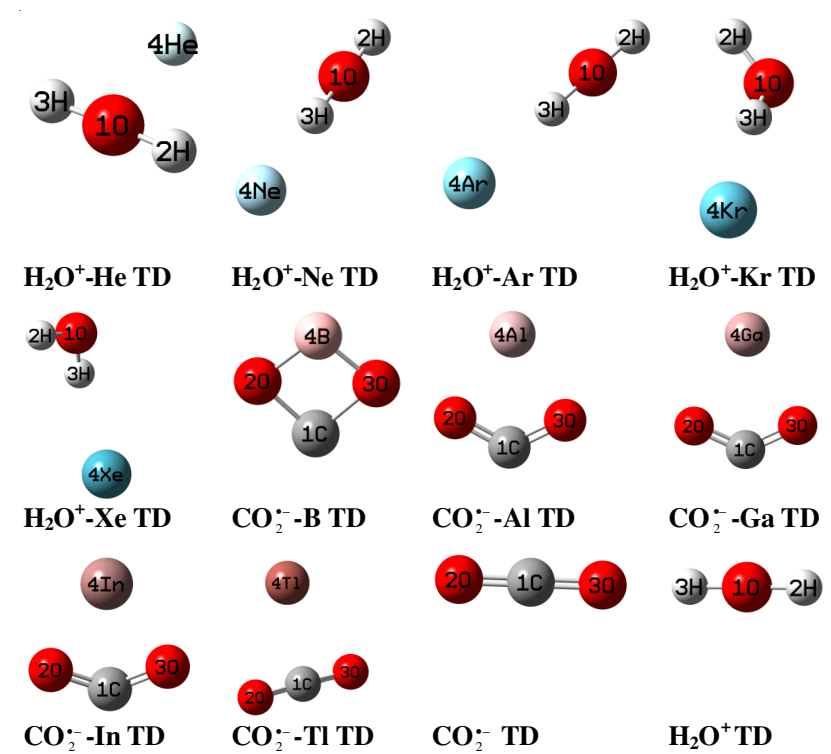

Fig. 2. Optimized excited structure of $\mathrm{H}_{2} \mathrm{O}^{+}-\mathrm{M}(\mathrm{He}, \mathrm{Ne}, \mathrm{Ar}, \mathrm{Kr}$ and $\mathrm{Xe}$ ) and $\mathrm{CO}_{2}{ }^{\circ-}-\mathrm{M}(\mathrm{B}, \mathrm{Al}, \mathrm{Ga}$, In and $\mathrm{Tl})$

\section{RESULTS AND DISCUSSION}

Parameters of $\mathrm{CO}_{2}{ }^{--}-\mathrm{M}(\mathrm{M}=\mathrm{B}, \mathrm{Al}$, Ga, In and Tl) geometric structure optimization: Ground state geometric structure parameters of $\mathrm{CO}_{2}{ }^{-}-\mathrm{M}(\mathrm{M}=\mathrm{B}, \mathrm{Al}, \mathrm{Ga}$, In and $\mathrm{Tl})$ were presented in Table-1. Structural parameters of (in this paper, the symbol has been used to refer to a carbon dioxide radical anion) at the same computational condition were as

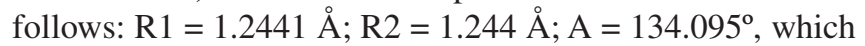
were basically consistent with the report by Indrakanti et al..$^{23}$ and the bond length of $\mathrm{C}-\mathrm{O}$ were $1.216 \AA$ and $1.372 \AA$ in $\mathrm{CO}_{2}{ }^{--}-\mathrm{B}$, one was lengthened and the other was shortened, therefore they are somewhat like the structure of $\mathrm{CO}_{3}{ }^{2-}$ and the bond length of C-B was $1.588 \AA$. Every bond length is lengthened according to the order from up to down in the same group from $\mathrm{B}$ to $\mathrm{Tl}$ compared to that of $\mathrm{CO}_{2}{ }^{--}$and every bond angle is reduced contrasted to that of $\mathrm{CO}_{2}{ }^{\circ-}$, the bond angle of $\mathrm{O}-\mathrm{C}-\mathrm{O}$ in $\mathrm{CO}_{2}^{-}-\mathrm{Al}$ is the smallest one among the five complexes. The dipole moment of $\mathrm{CO}_{2}{ }^{--}$was $0.1061 \mathrm{D}$ and the values of $\mathrm{CO}_{2}{ }^{--}-\mathrm{M}(\mathrm{M}=\mathrm{B}, \mathrm{Al}, \mathrm{Ga}$, In and $\mathrm{Tl})$ are all larger than that of $\mathrm{CO}_{2}{ }^{\circ-}$, the dipole moment value of $\mathrm{CO}_{2}{ }^{--}-\mathrm{Al}$ is the smallest one among the five complexes, which indicated that $\mathrm{CO}_{2}{ }^{-}-\mathrm{Al}$ is in better symmetry than the other four. It revealed that electrondefect atom might maintain the structure of $\mathrm{CO}_{2}{ }^{-1}$ like $\mathrm{CO}_{3}{ }^{2-}$, which is convenient for appropriate radicals reacting with $\mathrm{CO}_{2}{ }^{\circ-}$ to form the aim product or its precursor, therefore the electrondefect atom is favourable to the reaction herein.

\begin{tabular}{|c|c|c|c|c|c|}
\hline \multicolumn{6}{|c|}{$\begin{array}{c}\text { TABLE-1 } \\
\text { OPTIMIZED STRUCTURAL PARAMETERS } \\
\mathrm{OF} \mathrm{CO}_{2}{ }^{-}-\mathrm{M}(\mathrm{M}=\mathrm{B}, \mathrm{Al}, \mathrm{Ga} \text {, In and } \mathrm{Tl})\end{array}$} \\
\hline $\mathrm{CO}_{2}-\mathrm{M}^{\mathrm{a}}$ & $\mathrm{B}$ & $\mathrm{Al}$ & $\mathrm{Ga}$ & In & $\mathrm{Tl}$ \\
\hline $\mathrm{R}^{\mathrm{b}}$ & 1.2164 & 1.2203 & 1.2236 & 1.2231 & 1.2232 \\
\hline$\AA$ & 1.3716 & 1.3621 & 1.3253 & 1.3178 & 1.2768 \\
\hline$(1-2,1-3,1-4)$ & 1.5881 & 2.0121 & 2.0723 & 2.2696 & 2.5199 \\
\hline$A^{c}$ & 126.56 & 124.06 & 126.43 & 126.63 & 130.67 \\
\hline degree & 173.84 & 171.72 & 162.04 & 162.02 & 152.96 \\
\hline & 59.61 & 64.22 & 71.53 & 71.35 & 76.37 \\
\hline $\mathrm{Dm}^{\mathrm{d}} \mathrm{D}$ & 3.5463 & 0.4708 & 2.7100 & 4.5170 & 6.7763 \\
\hline $\begin{array}{l}{ }^{\mathrm{a}} \mathrm{M} \text { refers to } \mathrm{B} \\
\mathrm{b} \text { refers to th } \\
{ }^{\mathrm{c}} \mathrm{A} \text { refers to th } \\
{ }^{\mathrm{d}} \text { Dm refers to }\end{array}$ & $\begin{array}{l}\text { l, Ga, In, } \\
\text { ond lengt } \\
\text { ond angl } \\
\text { dipole } \mathrm{m}\end{array}$ & $\begin{array}{l}\text { of } \mathrm{O} 2-\mathrm{C} \\
\text { ment of }\end{array}$ & 03. & & \\
\hline
\end{tabular}

The excited state structure of complexes are much different from that of ground state as shown in Table-2 and Fig. 2.

$\mathrm{B}$ and $\mathrm{Ga}$ lengthened the bond length of $\mathrm{C}-\mathrm{O}$ in $\mathrm{CO}_{2}{ }^{-}-\mathrm{M}$ $(\mathrm{M}=\mathrm{B}, \mathrm{Al}, \mathrm{Ga}$, In and $\mathrm{Tl}$ ), while $\mathrm{Al}$, In and $\mathrm{Tl}$ shortened them, $\mathrm{Tl}$ especially made the bond length of $\mathrm{C}-\mathrm{O}$ to be triple bonds. According to the calculation the bond angles of $\mathrm{CO}_{2}{ }^{--}$ $-\mathrm{M}(\mathrm{M}=\mathrm{Al}, \mathrm{Ga}$ and $\mathrm{In})$ are close to the $s p^{2}$ hybridization of $\mathrm{C}$, while bond angles of $\mathrm{CO}_{2}{ }^{-}-\mathrm{M}(\mathrm{M}=\mathrm{B}$ and $\mathrm{Tl})$ are almost equal

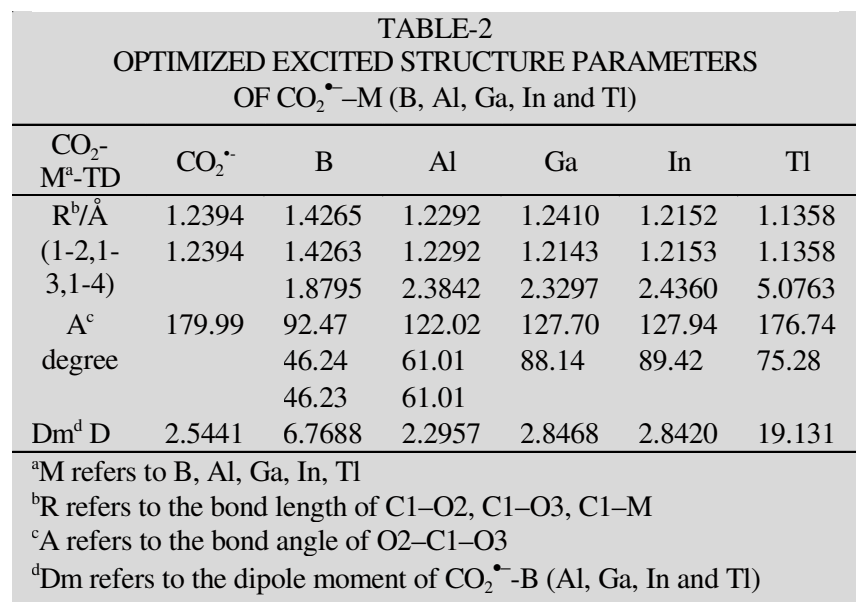




\begin{tabular}{|c|c|c|c|c|c|c|c|c|c|c|c|}
\hline \multicolumn{12}{|c|}{$\begin{array}{l}\text { TABLE-3 } \\
\text { ALYSIS OF CC }\end{array}$} \\
\hline $\mathrm{P}^{\mathrm{a}}$ & $\mathrm{N}^{\mathrm{b}}$ & \multicolumn{2}{|r|}{$\mathrm{CO}_{2}-\mathrm{B}$} & \multicolumn{2}{|r|}{$\mathrm{CO}_{2}-\mathrm{Al}$} & \multicolumn{2}{|c|}{$\mathrm{CO}_{2}-\mathrm{Ga}$} & \multicolumn{2}{|c|}{$\mathrm{CO}_{2}$-In } & \multicolumn{2}{|c|}{$\mathrm{CO}_{2}-\mathrm{Tl}$} \\
\hline \multirow{10}{*}{$\begin{array}{l}\text { Config- } \\
\text { uration } \\
\mathrm{e}^{-}\end{array}$} & \multirow[t]{3}{*}{$\mathrm{C}$} & \multicolumn{2}{|c|}{$2 \mathrm{~s}(0.97) 2 \mathrm{p}(2.52)$} & \multicolumn{2}{|c|}{$2 \mathrm{~s}(1.09) 2 \mathrm{p}(2.54)$} & \multicolumn{2}{|c|}{$2 \mathrm{~s}(1.04) 2 \mathrm{p}(2.54)$} & \multicolumn{2}{|c|}{$2 \mathrm{~s}(1.05) 2 \mathrm{p}(2.53)$} & \multicolumn{2}{|c|}{$2 \mathrm{~s}(0.99) 2 \mathrm{p}(2.50)$} \\
\hline & & \multicolumn{2}{|c|}{$3 \mathrm{~s}(0.02) 3 \mathrm{p}(0.02)$} & \multicolumn{2}{|c|}{$3 \mathrm{~s}(0.03) 3 \mathrm{p}(0.03)$} & \multicolumn{2}{|c|}{$3 \mathrm{~s}(0.03) 3 \mathrm{p}(0.04)$} & \multicolumn{2}{|c|}{$3 \mathrm{~s}(0.02) 3 \mathrm{p}(0.04)$} & \multicolumn{2}{|c|}{$3 \mathrm{~s}(0.02) 3 \mathrm{p}(0.04)$} \\
\hline & & \multicolumn{2}{|c|}{$3 \mathrm{~d}(0.02)$} & \multicolumn{2}{|c|}{$3 \mathrm{~d}(0.01)$} & \multicolumn{2}{|c|}{$3 \mathrm{~d}(0.02)$} & \multicolumn{2}{|c|}{$3 \mathrm{~d}(0.01)$} & \multicolumn{2}{|c|}{$3 \mathrm{~d}(0.01)$} \\
\hline & \multirow[t]{2}{*}{$\mathrm{O}$} & \multicolumn{2}{|c|}{$2 \mathrm{~s}(1.71) 2 \mathrm{p}(4.96)$} & \multicolumn{2}{|c|}{$2 \mathrm{~s}(1.71) 2 \mathrm{p}(4.97)$} & \multicolumn{2}{|c|}{$2 \mathrm{~s}(1.71) 2 \mathrm{p}(4.98)$} & \multicolumn{2}{|c|}{$2 \mathrm{~s}(1.71) 2 \mathrm{p}(4.98)$} & \multicolumn{2}{|c|}{$2 \mathrm{~s}(1.71) 2 \mathrm{p}(4.97)$} \\
\hline & & \multicolumn{2}{|c|}{$3 \mathrm{~d}(0.01)$} & \multicolumn{2}{|c|}{$3 \mathrm{~d}(0.01)$} & \multicolumn{2}{|c|}{$3 \mathrm{~d}(0.01)$} & $3 \mathrm{~d}(0.0$ & te & $3 \mathrm{~d}(0.01)$ & \\
\hline & $\mathrm{O}$ & $2 \mathrm{~s}$ & 4) $2 p(4.97)$ & & 77) $2 p(5.12)$ & $2 \mathrm{~s}(1$. & $2 \mathrm{p}(5.05)$ & $2 \mathrm{~s}(1.7 \mathrm{c}$ & $2 \mathrm{p}(5.07)$ & $2 \mathrm{~s}(1.74)$ & $(5.03)$ \\
\hline & & $3 \mathrm{~d}$ & & & .01) & $3 p(0$ & & & & $3 \mathrm{~d}(0.01)$ & \\
\hline & M & $2 \mathrm{~s}$ & 2) $2 p(1.39)$ & & 77) $3 p(0.90)$ & $4 \mathrm{~s}(1$. & $4 p(0.95)$ & $5 \mathrm{~s}(1.8$ & $5 p(0.94)$ & $6 s(1.94)$ & $(1.01)$ \\
\hline & & $3 \mathrm{~s}$ & 1) $3 p(0.01)$ & & 01) & $5 \mathrm{~s}(0$. & & $6 \mathrm{p}(0.0$ & & $7 p(0.01)$ & \\
\hline & & $3 \mathrm{~d}$ & & & $01) 4 p(0.02)$ & $4 \mathrm{~d}(0$ & $5 p(0.01)$ & & & & \\
\hline Charge & $\mathrm{O}$ & -0.718 & -0.674 & -0.900 & -0.691 & -0.822 & -0.704 & -0.839 & -0.704 & -0.786 & -0.700 \\
\hline $\mathrm{e}^{-}$ & $\mathrm{C} / \mathrm{M}$ & 0.445 & -0.053 & 0.290 & 0.300 & 0.344 & 0.182 & 0.337 & 0.206 & 0.431 & 0.054 \\
\hline Core & $\mathrm{O}$ & 2.000 & 2.000 & 2.000 & 2.000 & 2.000 & 2.000 & 2.000 & 2.000 & 2.000 & 2.000 \\
\hline $\mathrm{e}^{-}$ & $\mathrm{C} / \mathrm{M}$ & 1.999 & 2.000 & 2.000 & 9.999 & 2.000 & 27.99 & 2.000 & 46.00 & 2.000 & 77.99 \\
\hline Valence & $\mathrm{O}$ & 6.707 & 6.662 & 6.884 & 6.677 & 6.809 & 6.691 & 6.828 & 6.692 & 6.774 & 6.687 \\
\hline $\mathrm{e}^{-}$ & $\mathrm{C} / \mathrm{M}$ & 3.492 & 3.018 & 3.631 & 2.662 & 3.576 & 2.793 & 3.589 & 2.786 & 3.492 & 2.950 \\
\hline Rydberg & $\mathrm{O}$ & 0.011 & 0.012 & 0.015 & 0.014 & 0.013 & 0.013 & 0.011 & 0.012 & 0.012 & 0.013 \\
\hline $\mathrm{e}^{-}$ & $\mathrm{C} / \mathrm{M}$ & 0.063 & 0.036 & 0.080 & 0.039 & 0.081 & 0.030 & 0.075 & 0.007 & 0.077 & 0.006 \\
\hline Total & $\mathrm{O}$ & 8.718 & 8.674 & 8.900 & 8.691 & 8.822 & 8.704 & 8.839 & 8.704 & 8.786 & 8.70 \\
\hline $\mathrm{e}^{-}$ & $\mathrm{C} / \mathrm{M}$ & 5.555 & 5.053 & 5.710 & 12.70 & 5.657 & 30.82 & 5.663 & 48.79 & 5.569 & 80.95 \\
\hline
\end{tabular}

TABLE-4

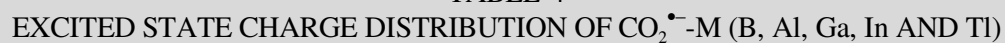

\begin{tabular}{ccccccc}
\hline Parameter $^{\mathrm{a}}$ & $\mathrm{CO}_{2}{ }^{--}$ & $\mathrm{B}^{\mathrm{b}}$ & $\mathrm{Al}$ & $\mathrm{Ga}$ & $\mathrm{In}$ & $\mathrm{Tl}$ \\
\hline Charge (TD) $^{\mathrm{e}^{-}}$ & $\mathrm{C} 0.274$ & $\mathrm{C} 0.189$ & $\mathrm{C} 0.132$ & $\mathrm{C} 0.213$ & $\mathrm{C} 0.196$ & $\mathrm{C} 0.721$ \\
& $\mathrm{O}-0.637$ & $\mathrm{O}-0.385$ & $\mathrm{O}-0.627$ & $\mathrm{O}-0.561$ & $\mathrm{O}-0617$ & $\mathrm{O}-0.368$ \\
& $\mathrm{O}-0.637$ & $\mathrm{O}-0.385$ & $\mathrm{O}-0.627$ & $\mathrm{O}-0.5616$ & $\mathrm{O}-0.617$ & $\mathrm{O}-0.368$ \\
& & $\mathrm{~B}-0.419$ & $\mathrm{Al0.121}$ & $\mathrm{Ga}-0.091$ & $\mathrm{In} 0.037$ & $\mathrm{Tl}-0.985$ \\
\hline
\end{tabular}

${ }^{a} \mathrm{P}$ Excited state charge distribution of $\mathrm{CO}_{2}{ }^{-}-\mathrm{M}(\mathrm{B}, \mathrm{Al}, \mathrm{Ga}$, In and $\mathrm{Tl})$ with the unit $\mathrm{e}^{-}$

${ }^{\mathrm{b}}$ Represents $\mathrm{C}, \mathrm{O}, \mathrm{O}, \mathrm{M}(\mathrm{M}=\mathrm{B}, \mathrm{Al}, \mathrm{Ga}$, In and $\mathrm{Tl})$ which marked on B only

to $180^{\circ}$. Dipole moment values of $\mathrm{CO}_{2}{ }^{\circ-}-\mathrm{M}(\mathrm{M}=\mathrm{Al}, \mathrm{Ga}$ and In) are all no more than $3 \mathrm{D}$, while that of $\mathrm{CO}_{2}{ }^{-{ }^{-}}-\mathrm{M}(\mathrm{M}=\mathrm{B}$ and $\mathrm{Tl})$ are much greater, which are consistent to bond angles.

Natural population analysis of $\mathrm{CO}_{2}{ }^{--}-\mathrm{M}(\mathrm{M}=\mathrm{B}, \mathrm{Al}$, Ga, In and Tl): The summary of ground state natural population of $\mathrm{CO}_{2}{ }^{--}-\mathrm{M}(\mathrm{M}=\mathrm{B}, \mathrm{Al}, \mathrm{Ga}$, In and $\mathrm{Tl})$ was given in Table-3 and they changed irregularly according to the order from up to down in the same group from B to Tl. The natural electron configuration on $\mathrm{C}$ and $\mathrm{O}$ atoms in complexes is different from that of them in $\mathrm{CO}_{2}{ }^{--}$and in $\mathrm{CO}_{2}{ }^{--}$there are $2.390 \mathrm{e}^{-}$in the $2 p$ orbital on $\mathrm{C}$ atom, while more than $2.500 \mathrm{e}^{-}$in the $2 p$ orbital on $\mathrm{C}$ atom in all $\mathrm{CO}_{2}{ }^{--}-\mathrm{M}(\mathrm{M}=\mathrm{B}, \mathrm{Al}, \mathrm{Ga}$, In and $\mathrm{Tl})$. Under the influence of $\mathrm{B}$ group elements the natural electron configuration of $\mathrm{O}$ atoms are imbalanced and even some electron cloud has been moved to the $3 d$ orbital. At the same time there is imbalanced electron distribution on B group elements for the different atomic radius and electronegativity. The charge distribution of $\mathrm{CO}_{2}{ }^{--}$is as follows: $0.513 \mathrm{e}^{-}$on $\mathrm{C}$ atom and $-0.756 \mathrm{e}^{-}$on $\mathrm{O}$ atoms, while no more than $0.444 \mathrm{e}^{-}$on the $\mathrm{C}$ atom of $\mathrm{CO}_{2}{ }^{--}-\mathrm{M}(\mathrm{M}=\mathrm{B}, \mathrm{Al}, \mathrm{Ga}$, In and $\mathrm{Tl})$ and like as the natural electron configuration of $\mathrm{O}$ atoms, the charge on $\mathrm{O}$ atoms are imbalanced, one is increased to $-0.898 \mathrm{e}^{-}$at most and the other is reduced to $-0.673 \mathrm{e}^{-}$in $\mathrm{CO}_{2}{ }^{--}-\mathrm{B}$. The charge on $\mathrm{B}$ group elements in $\mathrm{CO}_{2}{ }^{--}-\mathrm{M}(\mathrm{M}=\mathrm{B}, \mathrm{Al}, \mathrm{Ga}$, In and $\mathrm{Tl})$ is different for electronegativity and the interaction between $\mathrm{B}$ group elements and $\mathrm{CO}_{2}{ }^{-}$, therefore $\mathrm{B}$ is electronegative for getting some electron cloud from $\mathrm{CO}_{2}{ }^{--}$, while it is interesting that other elements gave some electron cloud to $\mathrm{CO}_{2}{ }^{-}$. There is almost no change of the distribution of electrons in all cores in the system. The valence is the sum of its theoretical valence and its charge for every atom. The Rydberg populations of $\mathrm{CO}_{2}{ }^{-}$is as follows: $0.118 \mathrm{e}^{-}$on $\mathrm{C}$ atom and $0.010 \mathrm{e}^{-}$on $\mathrm{O}$ atoms, therefore the $\mathrm{C}$ atom in $\mathrm{CO}_{2}{ }^{--}$is more active, while all are less than $0.081 \mathrm{e}^{-}\left(\mathrm{CO}_{2}^{-}-\mathrm{Ga}\right)$ on $\mathrm{C}$ atom in the other four, all of them are almost the same to $\mathrm{CO}_{2}{ }^{--}$in all the complexes on $\mathrm{O}$ atom and it indicated that $\mathrm{B}$ group elements activated the electron state.

The charge distribution of excited state of $\mathrm{CO}_{2}{ }^{-}-\mathrm{M}(\mathrm{M}=$ $\mathrm{B}, \mathrm{Al}, \mathrm{Ga}$, In and $\mathrm{Tl}$ ) are very interesting (Table-4). B, Ga and $\mathrm{Tl}$ are charged negatively and their values are $-0.4188 \mathrm{e}^{-}$, $-0.0905 \mathrm{e}^{-}$and $-0.9840 \mathrm{e}^{-}$respectively for their sharing capability of photoinduced electrons, while other boron group elements have positive charge which are $0.1209 \mathrm{e}^{-}$on $\mathrm{Al}$ and $0.0374 \mathrm{e}^{\mathrm{e}}$ on In, which is consistent to the charge distribution on $\mathrm{O}$ and $\mathrm{C}$. There was trade-off relationship between $\mathrm{O}$ and $\mathrm{C}$ as well as boron group elements.

Electronic transition: The qualitative molecular orbital representations of the highest occupied molecular orbitals (HOMOs) and the lowest unoccupied molecular orbitals (LUMOs) for $\mathrm{CO}_{2}{ }^{--}-\mathrm{M}(\mathrm{M}=\mathrm{B}, \mathrm{Al}, \mathrm{Ga}$, In and $\mathrm{Tl}$ ) are shown in Fig. 3. The energy gap of HOMOs and LUMOs is decline 
in $\mathrm{CO}_{2}^{-}-\mathrm{M}(\mathrm{M}=\mathrm{B}, \mathrm{Al}, \mathrm{Ga}$, In and $\mathrm{Tl})$ from up to down. Both the HOMOs and LUMOs have $\pi$ characters. Each HOMO $\rightarrow$ LUMO transition corresponds to a $\pi$ to $\pi^{*}$ excited singlet state. The excitation of the electron from the HOMO to the LUMO leads the electronic density to flow mainly from to B group elements in $\mathrm{CO}_{2}{ }^{-}-\mathrm{M}(\mathrm{M}=\mathrm{B}, \mathrm{Ga}$ and $\mathrm{Tl})$, while the situation is opposite to that of $\mathrm{CO}_{2}{ }^{\circ-}-\mathrm{M}(\mathrm{M}=\mathrm{B}, \mathrm{Ga}$ and $\mathrm{Tl})$ in $\mathrm{CO}_{2}{ }^{-{ }^{-}}-\mathrm{M}$ $(\mathrm{M}=\mathrm{Al}$ and $\mathrm{In})$.

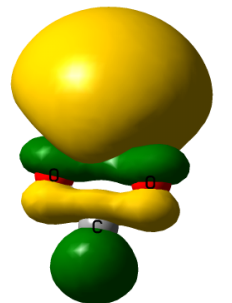

$\mathrm{CO}_{2}^{-}-\mathrm{B}-\mathrm{TD}-\mathrm{HOMO}$
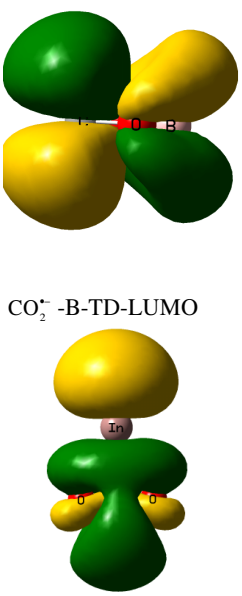

$\mathrm{CO}_{2}^{-}-\mathrm{In}-\mathrm{TD}-\mathrm{HOMO}$

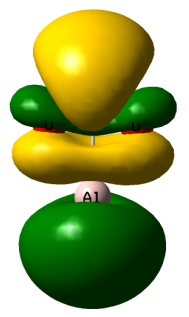

$\mathrm{CO}_{2}^{--}-\mathrm{Al}-\mathrm{TD}-\mathrm{HOMO}$

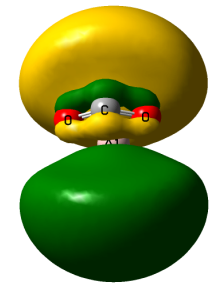

$\mathrm{CO}_{2}^{--}-\mathrm{Al}-\mathrm{TD}-\mathrm{LUMO}$

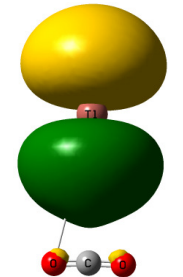

$\mathrm{CO}_{2}^{--}$-Tl-TD-HOMO

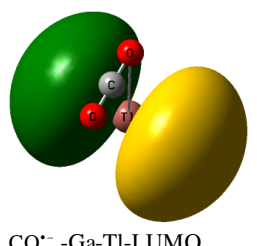

$\mathrm{CO}_{2}^{*-}$-Ga-Tl-LUMO

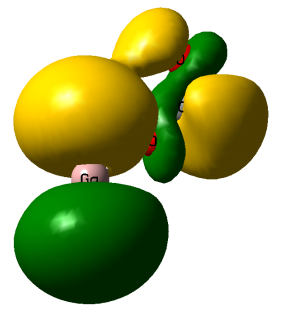

$\mathrm{CO}_{2}^{--}$-Ga-TD-HOMO

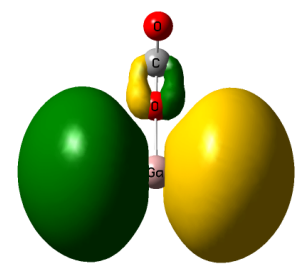

$\mathrm{CO}_{2}^{--}$-Ga-TD-LUMO

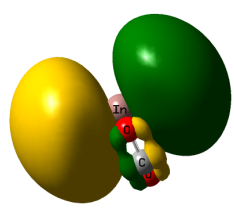

$\mathrm{CO}_{2}^{--}$-In-TD-LUMO
Fig. 3. Frontier orbital diagrams of $\mathrm{CO}_{2}{ }^{--}-\mathrm{M}(\mathrm{B}, \mathrm{Al}, \mathrm{Ga}$, In and $\mathrm{Tl})$
Energy parameters analysis of $\mathrm{CO}_{2}^{-}-\mathrm{M}(\mathrm{M}=\mathrm{B}, \mathrm{Al}$, Ga, In and Tl): Ground state thermochemistry parameters of $\mathrm{CO}_{2}{ }^{--}-\mathrm{M}(\mathrm{M}=\mathrm{B}, \mathrm{Al}, \mathrm{Ga}$, In and $\mathrm{Tl})$ are changed with the different element in B group (Table-5). The sum of electronic and zero-point energy ( $E_{\text {electronictzero-point }} \mathrm{kcal} / \mathrm{mol}$ ), the sum of electronic and thermal energy $\left(\mathrm{E}_{\text {electronicthermal }} \mathrm{kcal} / \mathrm{mol}\right)$, the sum of electronic and thermal enthalpy $\left(\mathrm{H}_{\text {electronictthermal }} \mathrm{kcal} / \mathrm{mol}\right)$ and the sum of electronic and thermal free energy $\mathrm{CO}_{2}{ }^{--}-\mathrm{M}$ $\left(\mathrm{G}_{\text {electronic+thermal }} \mathrm{kcal} / \mathrm{mol}\right)$ are increased from $\mathrm{B}$ to $\mathrm{Ga}$ and they are reduced to the lowest value in $\mathrm{CO}_{2}{ }^{-}-\mathrm{In}$ and in $\mathrm{CO}_{2}{ }^{-}-\mathrm{Tl}$ which are higher than that of $\mathrm{CO}_{2}{ }^{-}-\mathrm{B}$. As to the same element, the highest value among the four is the sum of electronic and thermal free energy $\left(\mathrm{G}_{\text {electronic+thermal }} \mathrm{kcal} / \mathrm{mol}\right)$ and the lowest value is the sum of electronic and thermal enthalpy $\left(\mathrm{H}_{\text {electronicthermal }}\right.$ $\mathrm{kcal} / \mathrm{mol}$ ). The highest (lowest value of entropy among the five complexes is in $\mathrm{CO}_{2}{ }^{-}-\mathrm{B}$ ) value of entropy among the five complexes is in $\mathrm{CO}_{2}{ }^{--}$- $\mathrm{Tl}$ according to the following formula: $\mathrm{S}=(\mathrm{H}-\mathrm{G}) / \mathrm{T}$, which is consistent with the geometrical parameters and the relative atomic mass of $\mathrm{B}, \mathrm{Al}, \mathrm{Ga}$, In and Tl. It is because of the increasing of the atomic number and the diminishing interaction between the $\mathrm{B}$ group elements and $\mathrm{CO}_{2}{ }^{\circ-}$.

There were three infrared absorption frequencies of $\mathrm{CO}_{2}{ }^{-}$ which were $740.66,1330.56$ and $1689.35 \mathrm{~cm}^{-1}$. The weak skeletal bending vibration of $\mathrm{CO}_{2}^{-}$- was at $740.66 \mathrm{~cm}^{-1}$, skeletal stretching vibration was at $1330.56 \mathrm{~cm}^{-1}$ and the $\mathrm{C}=\mathrm{O}$ strong stretching vibration of $\mathrm{CO}_{2}{ }^{--}$was at $1689.35 \mathrm{~cm}^{-1}$. In $\mathrm{CO}_{2}{ }^{--}-\mathrm{M}$ $(\mathrm{M}=\mathrm{B}, \mathrm{Al}, \mathrm{Ga}, \mathrm{In}$ and $\mathrm{Tl})$ there were 6 infrared absorption frequencies which were skeletal wagging vibration, the outof-plane bending vibration of the $\mathrm{C}$ atom, the in-plane bending vibration of the $\mathrm{O}-\mathrm{M}-\mathrm{O}(\mathrm{M}=\mathrm{B}, \mathrm{Al}, \mathrm{Ga}$, In and $\mathrm{Tl})$ chain, the in-plane bending vibration of the $\mathrm{O}=\mathrm{O}-\mathrm{M}$ chain, the in-plane bending vibration of the $\mathrm{C}-\mathrm{O}-\mathrm{M}$ chain and the in-plane bending vibration of the $\mathrm{C}=\mathrm{O}$ bond, which were one to one correspondence to the increasing frequencies among the 6 . The intensity of the latter 3 frequencies is stronger than that of the foregoing 3. The specific frequencies are different in $\mathrm{CO}_{2}{ }^{--}-\mathrm{M}(\mathrm{M}=\mathrm{B}$, $\mathrm{Al}, \mathrm{Ga}$, In and $\mathrm{Tl}$ ) because of the different strength of the $\mathrm{C}-\mathrm{M}$ bond and symmetry of the complexes.

The excited state energy parameters of $\mathrm{CO}_{2}{ }^{-}-\mathrm{M}(\mathrm{M}=\mathrm{B}$, $\mathrm{Al}, \mathrm{Ga}, \mathrm{In}$ and $\mathrm{Tl}$ ) are transition energy, amplitude and maximum

TABLE-5

GROUND STATE THERMOCHEMISTRY PARAMETERS OF CO ${ }_{2}^{\circ-}-\mathrm{M}(\mathrm{M}=\mathrm{B}, \mathrm{Al}, \mathrm{Ga}$ In AND Tl)

\begin{tabular}{|c|c|c|c|c|c|c|c|c|c|c|}
\hline Parameter $^{\mathrm{a}}$ & \multicolumn{2}{|c|}{$\mathrm{CO}_{2}-\mathrm{B}$} & \multicolumn{2}{|c|}{$\mathrm{CO}_{2}-\mathrm{Al}$} & \multicolumn{2}{|c|}{$\mathrm{CO}_{2}-\mathrm{Ga}$} & \multicolumn{2}{|c|}{$\mathrm{CO}_{2}-\mathrm{In}$} & \multicolumn{2}{|c|}{$\mathrm{CO}_{2}-\mathrm{Tl}$} \\
\hline \multirow{4}{*}{ Freq $^{b}\left(\mathrm{~cm}^{-1}\right)$} & 382.47 & 468.63 & 315.49 & 360.12 & 229.41 & 348.42 & 228.81 & 283.41 & 187.02 & 213.22 \\
\hline & 701.09 & 868.15 & 523.23 & 733.91 & 373.01 & 732.68 & 353.48 & 728.32 & 343.77 & 697.36 \\
\hline & 1089.9 & 1793.7 & 1004.4 & 1701.4 & 1086.7 & 1683.4 & 1077.8 & 1678.0 & 1138.6 & 1706.1 \\
\hline & 2.60 & 47.43 & 9.33 & 6.72 & 15.62 & 41.98 & 14.74 & 14.01 & 13.23 & 3.08 \\
\hline \multirow[t]{2}{*}{$\operatorname{IR} \operatorname{Inten}^{\mathrm{c}}(\mathrm{km} / \mathrm{mol})$} & 64.71 & 85.57 & 54.04 & 29.37 & 5.03 & 56.51 & 3.84 & 105.30 & 2.13 & 384.38 \\
\hline & 87.88 & 256.78 & 84.87 & 560.40 & 129.14 & 631.16 & 199.25 & 771.81 & 619.96 & 788.47 \\
\hline $\mathrm{E}_{\text {electronic+zero-pointd }} \mathrm{kcal} / \mathrm{mol}$ & \multicolumn{2}{|c|}{-133906.87} & \multicolumn{2}{|c|}{-270508.26} & \multicolumn{2}{|c|}{-1326240.50} & \multicolumn{2}{|c|}{-119544.42} & \multicolumn{2}{|c|}{-150748.61} \\
\hline $\mathrm{E}_{\text {electronictthermale }} \mathrm{kcal} / \mathrm{mol}$ & \multicolumn{2}{|c|}{-133901.85} & \multicolumn{2}{|c|}{-270503.24} & \multicolumn{2}{|c|}{-1326235.48} & \multicolumn{2}{|c|}{-119538.77} & \multicolumn{2}{|c|}{-150832.70} \\
\hline $\mathrm{H}_{\text {electronictthermalf }} \mathrm{kcal} / \mathrm{mol}$ & \multicolumn{2}{|c|}{-133900.59} & \multicolumn{2}{|c|}{-270501.99} & \multicolumn{2}{|c|}{-1326234.23} & \multicolumn{2}{|c|}{-119537.52} & \multicolumn{2}{|c|}{-150741.71} \\
\hline $\mathrm{G}_{\text {electronictthermalg }} \mathrm{kcal} / \mathrm{mol}$ & \multicolumn{2}{|c|}{-133938.24} & \multicolumn{2}{|c|}{-270541.52} & \multicolumn{2}{|c|}{-1326275.63} & \multicolumn{2}{|c|}{-119580.19} & \multicolumn{2}{|c|}{-150786.26} \\
\hline
\end{tabular}

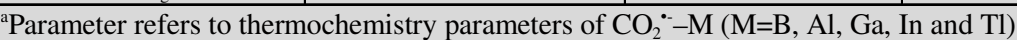

${ }^{b}$ Freq refers to the infrared absorption frequencies

'IR Inten refers to the infrared absorption intensity

${ }^{\mathrm{d}}$ E electronic and zero-point (A.U) refers to the sum of electronic and zero-point energy of $\mathrm{CO}_{2}{ }^{-}-\mathrm{M}^{-}$

${ }^{\mathrm{e}} \mathrm{E}$ electronic and thermal (A.U) refers to the sum of electronic and thermal energy of $\mathrm{CO}_{2}{ }^{-}-\mathrm{M}^{2}$

${ }^{\mathrm{f}} \mathrm{H}$ electronic and thermal (A.U) refers to the sum of electronic and thermal enthalpy of $\mathrm{CO}_{2}{ }^{-}-\mathrm{M}$

${ }^{\mathrm{g}} \mathrm{G}$ electronic and thermal (A.U) refers to the sum of electronic and thermal free energy $\mathrm{CO}_{2}{ }^{\circ}-\mathrm{M}$ 
absorption wavelength shown in Table- 6 . The transition energy values of $\mathrm{CO}_{2}{ }^{--}-\mathrm{M}(\mathrm{M}=\mathrm{B}, \mathrm{Al}, \mathrm{Ga}$ and $\mathrm{In})$ are between 4 and $5 \mathrm{eV}$, while that of $\mathrm{CO}_{2}{ }^{--}-\mathrm{Tl}$ is $5.24 \mathrm{eV}$, which are greater than that of pure $\mathrm{TiO}_{2}$ acted as photocatalyst in the reaction system. Amplitudes of $\mathrm{CO}_{2}{ }^{-}-\mathrm{B}$ is minimum $(\mathrm{f}=0.1122)$ among the five complexes and that of $\mathrm{CO}_{2}{ }^{-}-\mathrm{In}$ is the maximum one (1.1924). The maximum absorption wavelength of $\mathrm{CO}_{2}{ }^{\circ-}-\mathrm{Ga}$ is at $308.32 \mathrm{~nm}$ and that of $\mathrm{CO}_{2}^{--}$-In is at $282.63 \mathrm{~nm}$, which are consistent to their larger amplitude and smaller transition energy, therefore $\mathrm{Ga}$ is helpful to the reaction system among the five elements, which is consistent with literature ${ }^{24}$. While other complexes absorption peak are under $270 \mathrm{~nm}$.

TABLE-6

EXCITED PARAMETERS OF $\mathrm{H}_{2} \mathrm{O}^{+}-\mathrm{M}(\mathrm{He}, \mathrm{Ne}, \mathrm{Ar}, \mathrm{Kr}$ AND Xe)

AND $\mathrm{CO}_{2}{ }^{-}-\mathrm{M}(\mathrm{B}, \mathrm{Al}, \mathrm{Ga}$, In AND Tl), INCLUDING EXCITED

ENERGY, AMPLITUDE AND MAXIMUM ABSORPTION WAVELENGTH

\begin{tabular}{|c|c|c|c|}
\hline $\begin{array}{l}\text { Complex }^{\mathrm{a}} \\
\text { (TD) }\end{array}$ & $\begin{array}{c}\text { Transition } \\
\text { energy }^{\mathrm{b}}(\mathrm{eV})\end{array}$ & $\begin{array}{l}\text { Amplitude }^{c} \\
\text { (f) }\end{array}$ & $\begin{array}{c}\text { Max wavelength } \\
(\mathrm{nm})\end{array}$ \\
\hline $\mathrm{H}_{2} \mathrm{O}^{+}$ & 10.7592 & 0.0001 & 115.24 \\
\hline $\mathrm{H}_{2} \mathrm{O}^{+}-\mathrm{He}$ & 10.7645 & 0.0001 & 115.18 \\
\hline $\mathrm{H}_{2} \mathrm{O}^{+}-\mathrm{Ne}$ & 11.0380 & 0.0001 & 112.32 \\
\hline $\mathrm{H}_{2} \mathrm{O}^{+}-\mathrm{Ar}$ & 8.1887 & 0.0001 & 151.41 \\
\hline $\mathrm{H}_{2} \mathrm{O}^{+}-\mathrm{Kr}$ & 4.1320 & 0.0405 & 300.06 \\
\hline $\mathrm{H}_{2} \mathrm{O}^{+}-\mathrm{Xe}$ & 2.4500 & 0.0768 & 506.06 \\
\hline $\mathrm{CO}_{2}^{\bullet}$ & 1.6893 & 0.0121 & 733.92 \\
\hline $\mathrm{CO}_{2}^{\circ-}-\mathrm{B}$ & 4.7202 & 0.1122 & 262.67 \\
\hline $\mathrm{CO}_{2}^{\bullet-}-\mathrm{Al}$ & 4.6712 & 0.5353 & 265.42 \\
\hline $\mathrm{CO}_{2}^{\bullet-}-\mathrm{Ga}$ & 4.0213 & 0.8580 & 308.32 \\
\hline $\mathrm{CO}_{2}^{-}-\mathrm{In}$ & 4.3868 & 1.1924 & 282.63 \\
\hline $\mathrm{CO}_{2}{ }^{-}-\mathrm{Tl}$ & 5.2400 & 0.2684 & 236.61 \\
\hline
\end{tabular}

${ }^{a}$ Refers to complexes of $\mathrm{H}_{2} \mathrm{O}^{+}-\mathrm{M}(\mathrm{He}, \mathrm{Ne}, \mathrm{Ar}, \mathrm{Kr}$ and $\mathrm{Xe})$ and $\mathrm{CO}_{2}^{-}{ }_{-}^{-}$ $\mathrm{M}(\mathrm{B}, \mathrm{Al}, \mathrm{Ga}$, In and $\mathrm{Tl})$; ${ }^{b}$ Refers to excited Energy of $\mathrm{H}_{2} \mathrm{O}^{+}-\mathrm{M}(\mathrm{He}$, $\mathrm{Ne}, \mathrm{Ar}, \mathrm{Kr}$ and $\mathrm{Xe})$ and $\mathrm{CO}_{2}{ }^{-}-\mathrm{M}(\mathrm{B}, \mathrm{Al}, \mathrm{Ga}$, In and $\mathrm{Tl})$; ${ }^{\circ}$ Refers to amplitudes of $\mathrm{H}_{2} \mathrm{O}^{+}-\mathrm{M}(\mathrm{He}, \mathrm{Ne}, \mathrm{Ar}, \mathrm{Kr}$ and $\mathrm{Xe})$ and $\mathrm{CO}_{2}{ }^{-}-\mathrm{M}(\mathrm{B}, \mathrm{Al}$, $\mathrm{Ga}$, In and $\mathrm{Tl}$ ); ${ }^{\mathrm{d}}$ Refers to maximum absorption wavelengths of $\mathrm{H}_{2} \mathrm{O}^{+}-$ $\mathrm{M}(\mathrm{He}, \mathrm{Ne}, \mathrm{Ar}, \mathrm{Kr}$ and $\mathrm{Xe})$ and $\mathrm{CO}_{2}{ }^{-}-\mathrm{M}(\mathrm{B}, \mathrm{Al}, \mathrm{Ga}$, In and $\mathrm{Tl})$.

Parameters of $\mathrm{H}_{2} \mathrm{O}^{+}$-M ( $\mathrm{He}, \mathrm{Ne}, \mathrm{Ar}, \mathrm{Kr}$ and $\mathrm{Xe}$ ) optimization structure: Ground state structural parameters of $\mathrm{H}_{2} \mathrm{O}^{+}$$\mathrm{M}$ ( $\mathrm{He}, \mathrm{Ne}, \mathrm{Ar}, \mathrm{Kr}$ and $\mathrm{Xe}$ ) were presented in Table-7. They are regularly changed according to the order from up to down in the same group from He to Xe. Structural parameters of $\mathrm{H}_{2} \mathrm{O}^{+}$at the same computational condition were as follows: $\mathrm{R} 1=\mathrm{R} 2=1.002 \AA ; \mathrm{A}=111.407$ degree and the bond length of $\mathrm{H}-\mathrm{O}$ was $1.002 \AA$ in $\mathrm{H}_{2} \mathrm{O}^{+}$-He and the bond length of O-He was $2.309 \AA$. All bond lengths are shortened according to the order from up to down in the same group from He to Xe compared to that of $\mathrm{H}_{2} \mathrm{O}^{+}$and all bond angle are reduced contrasted to that of $\mathrm{H}_{2} \mathrm{O}^{+}$and $\mathrm{Ne}-\mathrm{O}$ bond is the shortest one among the five complexes for the strongest interaction between $\mathrm{H}_{2} \mathrm{O}^{+}-\mathrm{Ne}$ and the bond angle of $\mathrm{H}-\mathrm{O}-\mathrm{H}$ in $\mathrm{H}_{2} \mathrm{O}^{+}-\mathrm{Xe}$ is the smallest one among the five complexes. The dipole moment of $\mathrm{H}_{2} \mathrm{O}^{+}$was $2.373 \mathrm{D}$ and the values of $\mathrm{H}_{2} \mathrm{O}^{+}-\mathrm{He}(\mathrm{Ne}, \mathrm{Ar}, \mathrm{Kr}$ and $\mathrm{Xe}$ ) are all larger than that of $\mathrm{H}_{2} \mathrm{O}^{+}$. The dipole moment value of $\mathrm{H}_{2} \mathrm{O}^{+}-\mathrm{He}$ is the smallest one among the five complexes, which indicated that $\mathrm{H}_{2} \mathrm{O}^{+}$-He is in better symmetry than the other four. It is interesting that all complexes have shorter bond length than that of $\mathrm{H}_{2} \mathrm{O}^{+}$and the rare gas elements tend to inert $\mathrm{H}_{2} \mathrm{O}^{+}$back to the structure of $\mathrm{H}_{2} \mathrm{O}$.

\section{TABLE-7}

GROUND STATE OPTIMIZED STRUCTURAL PARAMETERS OF $\mathrm{H}_{2} \mathrm{O}^{+}-\mathrm{M}(\mathrm{M}=\mathrm{He}, \mathrm{Ne}, \mathrm{Ar}, \mathrm{Kr}$ and $\mathrm{Xe})$

\begin{tabular}{lccccc}
\hline $\mathrm{H}_{2} \mathrm{O}-\mathrm{M}^{\mathrm{a}}$ & $\mathrm{He}$ & $\mathrm{Ne}$ & $\mathrm{Ar}$ & $\mathrm{Kr}$ & $\mathrm{Xe}$ \\
\hline $\mathrm{R}^{\mathrm{b}}$ & 1.0016 & 0.9988 & 0.9872 & 0.9817 & 1.2232 \\
$\AA$ & 1.0016 & 0.9988 & 0.9871 & 0.9817 & 1.2768 \\
$(1-2,1-3,1-4)$ & 2.3088 & 2.2711 & 2.4002 & 2.4657 & 2.5199 \\
$\mathrm{~A}^{\mathrm{co}}$ & 111.28 & 111.01 & 109.54 & 108.93 & 106.50 \\
$\mathrm{Dm}^{\mathrm{d}} \mathrm{D}$ & 2.8948 & 5.4808 & 5.0562 & 5.3535 & 4.9312 \\
\hline
\end{tabular}

${ }^{\mathrm{a}} \mathrm{M}$ refers to $\mathrm{He}, \mathrm{Ne}, \mathrm{Ar}, \mathrm{Kr}, \mathrm{Xe}$; ${ }^{\mathrm{b}} \mathrm{R}$ refers to the bond length of $\mathrm{O} 1-$ $\mathrm{H} 2, \mathrm{O} 1-\mathrm{H} 3, \mathrm{O} 1-\mathrm{M}$; ${ }^{\mathrm{c}} \mathrm{A}$ refers to the bond angle of $\mathrm{H} 2-\mathrm{O} 1-\mathrm{H} 3$; ${ }^{\mathrm{d}} \mathrm{Dm}$ refers to the dipole moment of $\mathrm{H}_{2} \mathrm{O}^{+}-\mathrm{M}(\mathrm{M}=\mathrm{He}, \mathrm{Ne}, \mathrm{Ar}, \mathrm{Kr}$ and $\mathrm{Xe})$

The excited state structure of complexes are much different from that of ground state as shown in Table- 8 and Fig. 2. The bond length of $\mathrm{H}-\mathrm{O}$ is almost equal in every complex $\mathrm{H}_{2} \mathrm{O}^{+}-\mathrm{M}$ which is between 0.9697 and 0.9943 , while bond angles are close to that of $\mathrm{H}_{2} \mathrm{O}^{+}$in $\mathrm{H}_{2} \mathrm{O}^{+}-\mathrm{M}(\mathrm{He}, \mathrm{Ne}$ and $\mathrm{Ar}$ ) and bond angles in $\mathrm{H}_{2} \mathrm{O}^{+}-\mathrm{M}(\mathrm{Kr}$ and $\mathrm{Xe})$ are far from above values which are about $114^{\circ}$. It is interesting that all dipole moment values of $\mathrm{H}_{2} \mathrm{O}^{+}-\mathrm{M}(\mathrm{He}, \mathrm{Ne}, \mathrm{Ar}, \mathrm{Kr}$ and $\mathrm{Xe})$ are between $9 \mathrm{D}$ and $10 \mathrm{D}$ which are much larger than that of $\mathrm{H}_{2} \mathrm{O}^{+}$.

\begin{tabular}{lcccccc}
\hline \multicolumn{7}{c}{ TABLE-8 } \\
OPTIMIZED EXCITED STRUCTURE PARAMETERS \\
OF $\mathrm{H}_{2} \mathrm{O}^{+}-\mathrm{M}(\mathrm{He}, \mathrm{Ne}, \mathrm{Ar}, \mathrm{Kr}$ AND Xe) \\
\hline $\mathrm{H}_{2} \mathrm{O}-\mathrm{M}^{\mathrm{a}}-\mathrm{TD}$ & $\mathrm{H}_{2} \mathrm{O}^{+}$ & $\mathrm{He}$ & $\mathrm{Ne}$ & $\mathrm{Ar}$ & $\mathrm{Kr}$ & $\mathrm{Xe}$ \\
\hline $\mathrm{R}^{\mathrm{b}}$ & 0.9735 & 0.9735 & 0.9721 & 0.9697 & 0.978 & 0.9780 \\
$\AA$ & 0.9735 & 0.9735 & 0.9774 & 0.9943 & 0.986 & 0.9886 \\
$(1-2,1-3,1-4)$ & 179.9 & 3.408 & 1.859 & 2.014 & 2.511 & 2.669 \\
$\mathrm{~A}^{\mathrm{c}}$ & & 178.7 & 179.9 & 180.0 & 113.8 & 114.8 \\
$\mathrm{Dm}^{\mathrm{d}} \mathrm{D}$ & 2.633 & 9.810 & 9.276 & 9.537 & 9.388 & 9.90 \\
\hline
\end{tabular}

${ }^{\mathrm{a}} \mathrm{M}$ refers to $\mathrm{He}, \mathrm{Ne}, \mathrm{Ar}, \mathrm{Kr}, \mathrm{Xe} ;{ }^{b} \mathrm{R}$ refers to the bond length of $\mathrm{O} 1-\mathrm{H} 2$, $\mathrm{O} 1-\mathrm{H} 3, \mathrm{O} 1-\mathrm{M}$; ${ }^{\mathrm{c}} \mathrm{A}$ refers to the bond angle of $\mathrm{H} 2-\mathrm{O} 1-\mathrm{H} 3$; ${ }^{\mathrm{d}} \mathrm{Dm}$ refers to the dipole moment of $\mathrm{H}_{2} \mathrm{O}^{+}-\mathrm{M}(\mathrm{M}=\mathrm{He}, \mathrm{Ne}, \mathrm{Ar}, \mathrm{Kr}$ and $\mathrm{Xe})$

Summary of natural population of $\mathrm{H}_{2} \mathrm{O}^{+}-\mathrm{M}(\mathrm{He}, \mathrm{Ne}$, $\mathrm{Ar}, \mathrm{Kr}$ and $\mathrm{Xe}$ ): The summary of ground state natural population of $\mathrm{H}_{2} \mathrm{O}^{+}-\mathrm{M}$ ( $\mathrm{He}, \mathrm{Ne}, \mathrm{Ar}, \mathrm{Kr}$ and $\mathrm{Xe}$ ) was listed in Table-9 and they are changed with irregular according to the order from up to down in the same group from He to Xe. The natural electron configuration of $\mathrm{H}$ and $\mathrm{O}$ atoms in the complexes is different from that of them in $\mathrm{H}_{2} \mathrm{O}^{+}$. In $\mathrm{H}_{2} \mathrm{O}^{+}$there are $1.810 \mathrm{e}^{-}$ in the $2 s$ orbital and $4.260 \mathrm{e}^{-}$in the $2 p$ orbital of $\mathrm{O}$ atom, while less than $1.800 \mathrm{e}^{-}$in every $2 s$ orbital and more than $4.270 \mathrm{e}^{-}$in every $2 p$ orbital in $\mathrm{H}_{2} \mathrm{O}^{+}-\mathrm{M}(\mathrm{He}, \mathrm{Ne}, \mathrm{Ar}, \mathrm{Kr}$ and $\mathrm{Xe}$ ), under the effect of the rare gas elements the natural electron configuration of $\mathrm{O}$ atoms are increased in $\mathrm{H}_{2} \mathrm{O}^{+}-\mathrm{M}(\mathrm{He}, \mathrm{Ne}, \mathrm{Ar}, \mathrm{Kr}$ and $\mathrm{Xe}$ ), even some electron cloud has been moved to the $3 d$ orbital and the natural electron configuration of $\mathrm{H}$ atoms are increased in $\mathrm{H}_{2} \mathrm{O}^{+}$- $\mathrm{Ar}(\mathrm{Kr}, \mathrm{Xe})$. At the same time there is imbalanced electron distribution on the rare gas elements for the different atomic radius and electronegativity. The charge distribution of $\mathrm{H}_{2} \mathrm{O}^{+}$is as follows: $0.535 \mathrm{e}^{-}$on $\mathrm{H}$ atoms and $-0.070 \mathrm{e}^{-}$on $\mathrm{O}$ atom, while no more than $0.536 \mathrm{e}^{-}$on $\mathrm{H}$ atoms of $\mathrm{H}_{2} \mathrm{O}^{+}-\mathrm{He}$ $(\mathrm{Ne}, \mathrm{Ar}, \mathrm{Kr}$ and $\mathrm{Xe}$ ) and as well as the natural electron configuration of $\mathrm{O}$ atom, the charge distribution of $\mathrm{O}$ atom is increased from $\mathrm{He}$ to $\mathrm{Xe}$ and there is no less than $0.084 \mathrm{e}^{-}$on $\mathrm{O}$ atom in $\mathrm{H}_{2} \mathrm{O}^{+}-\mathrm{M}$ ( $\mathrm{He}, \mathrm{Ne}, \mathrm{Ar}, \mathrm{Kr}$ and $\mathrm{Xe}$ ). The charge distribution of the rare gas elements in $\mathrm{H}_{2} \mathrm{O}^{+}-\mathrm{M}(\mathrm{He}, \mathrm{Ne}, \mathrm{Ar}, \mathrm{Kr}$ and $\mathrm{Xe})$ is different for the strength of the interaction between rare 


\begin{tabular}{|c|c|c|c|c|c|c|c|c|c|c|c|}
\hline \multicolumn{12}{|c|}{$\begin{array}{c}\text { TABLE-9 } \\
\text { GROUND STATE NATURAL POPULATION ANALYSIS }\end{array}$} \\
\hline Parameter $^{\mathrm{a}}$ & $\mathrm{N}^{\mathrm{b}}$ & \multicolumn{2}{|l|}{$\mathrm{H}_{2} \mathrm{O}-\mathrm{He}$} & \multicolumn{2}{|c|}{$\mathrm{H}_{2} \mathrm{O}-\mathrm{Ne}$} & \multicolumn{2}{|l|}{$\mathrm{H}_{2} \mathrm{O}-\mathrm{Ar}$} & \multicolumn{2}{|l|}{$\mathrm{H}_{2} \mathrm{O}-\mathrm{Kr}$} & \multicolumn{2}{|c|}{$\mathrm{H}_{2} \mathrm{O}-\mathrm{Xe}$} \\
\hline \multirow{5}{*}{$\begin{array}{l}\text { Config- } \\
\text { uration } \\
\mathrm{e}^{-}\end{array}$} & \multirow[t]{2}{*}{$\mathrm{O}$} & \multirow{2}{*}{\multicolumn{2}{|c|}{$\begin{array}{l}2 \mathrm{~s}(1.80) 2 \mathrm{p}(4.27) \\
3 \mathrm{~d}(0.01)\end{array}$}} & \multicolumn{2}{|c|}{$2 \mathrm{~s}(1.80) 2 \mathrm{p}(4.32)$} & \multicolumn{2}{|c|}{$2 \mathrm{~s}(1.79) 2 \mathrm{p}(4.57)$} & \multicolumn{2}{|c|}{$2 \mathrm{~s}(1.78) 2 \mathrm{p}(4.71)$} & \multicolumn{2}{|c|}{$2 \mathrm{~s}(1.77) 2 \mathrm{p}(4.85)$} \\
\hline & & & & \multicolumn{2}{|c|}{$3 \mathrm{~d}(0.01)$} & \multicolumn{2}{|c|}{$3 \mathrm{~d}(0.01)$} & \multicolumn{2}{|c|}{$3 \mathrm{~d}(0.01)$} & \multicolumn{2}{|c|}{$3 \mathrm{~d}(0.01)$} \\
\hline & $\mathrm{H}$ & \multicolumn{2}{|c|}{$1 \mathrm{~s}(0.46)$} & \multicolumn{2}{|c|}{$1 \mathrm{~s}(0.46)$} & \multicolumn{2}{|c|}{$1 \mathrm{~s}(0.47)$} & \multicolumn{2}{|c|}{$1 \mathrm{~s}(0.48)$} & \multicolumn{2}{|c|}{$1 \mathrm{~s}(0.48)$} \\
\hline & $\mathrm{H}$ & \multicolumn{2}{|l|}{$1 \mathrm{~s}(0.46)$} & $1 \mathrm{~s}(0.46$ & & \multirow{2}{*}{\multicolumn{2}{|c|}{$\begin{array}{l}1 \mathrm{~s}(0.47) \\
3 \mathrm{~s}(2.00) 3 \mathrm{p}(5.69)\end{array}$}} & \multirow{2}{*}{\multicolumn{2}{|c|}{$\begin{array}{l}1 \mathrm{~s}(0.48) \\
4 \mathrm{~s}(2.00) 4 \mathrm{p}(5.55)\end{array}$}} & \multicolumn{2}{|c|}{$1 \mathrm{~s}(0.48)$} \\
\hline & M & \multicolumn{2}{|l|}{$1 \mathrm{~s}(1.99)$} & \multicolumn{2}{|c|}{$2 \mathrm{~s}(2.00) 2 \mathrm{p}(5.94)$} & & & & & $5 \mathrm{~s}(2.00$ & $\mathrm{p}(5.40)$ \\
\hline Charge & $\mathrm{H}$ & 0.536 & 0.536 & 0.535 & 0.535 & 0.527 & 0.527 & 0.521 & 0.521 & 0.515 & 0.515 \\
\hline$e^{-}$ & $\mathrm{O} / \mathrm{M}$ & -0.084 & 0.012 & -0.126 & 0.057 & -0.366 & 0.312 & -0.494 & 0.452 & -0.633 & 0.603 \\
\hline Core & $\mathrm{H}$ & 0.000 & 0.000 & 0.000 & 0.000 & 0.000 & 0.000 & 0.000 & 0.000 & 0.000 & 0.000 \\
\hline$e^{-}$ & $\mathrm{O} / \mathrm{M}$ & 2.000 & 0.000 & 2.000 & 2.000 & 2.000 & 10.00 & 2.000 & 28.00 & 2.000 & 46.00 \\
\hline Valence & $\mathrm{H}$ & 0.462 & 0.462 & 0.463 & 0.463 & 0.471 & 0.471 & 0.477 & 0.477 & 0.481 & 0.481 \\
\hline $\mathrm{e}^{-}$ & $\mathrm{O} / \mathrm{M}$ & 6.076 & 1.988 & 6.117 & 7.943 & 6.357 & 7.686 & 6.485 & 7.54 & 6.623 & 7.396 \\
\hline Rydberg & $\mathrm{H}$ & 0.002 & 0.002 & 0.002 & 0.002 & 0.002 & 0.002 & 0.002 & 0.002 & 0.004 & 0.004 \\
\hline $\mathrm{e}^{-}$ & $\mathrm{O} / \mathrm{M}$ & 0.007 & 0.000 & 0.009 & 0.000 & 0.009 & 0.002 & 0.009 & 0.003 & 0.010 & 0.000 \\
\hline Total & $\mathrm{H}$ & 0.464 & 0.464 & 0.465 & 0.465 & 0.473 & 0.473 & 0.479 & 0.479 & 0.485 & 0.485 \\
\hline $\mathrm{e}^{-}$ & $\mathrm{O} / \mathrm{M}$ & 8.084 & 1.988 & 8.126 & 9.943 & 8.366 & 17.69 & 8.494 & 35.55 & 8.633 & 53.40 \\
\hline
\end{tabular}

TABLE-10

EXCITED STATE CHARGE DISTRIBUTION OF $\mathrm{H}_{2} \mathrm{O}^{+}-\mathrm{M}(\mathrm{He}, \mathrm{Ne}, \mathrm{Ar}, \mathrm{Kr}$ AND Xe)

\begin{tabular}{lcccccc}
\hline Parameter $^{a}$ & $\mathrm{H}_{2} \mathrm{O}^{+}$ & $\mathrm{H}_{2} \mathrm{O}-\mathrm{He}^{\mathrm{b}}$ & $\mathrm{H}_{2} \mathrm{O}-\mathrm{Ne}$ & $\mathrm{H}_{2} \mathrm{O}-\mathrm{Ar}$ & $\mathrm{H}_{2} \mathrm{O}-\mathrm{Kr}$ & $\mathrm{H}_{2} \mathrm{O}-\mathrm{Xe}$ \\
\hline Charge (TD) $^{-}$ & $\mathrm{O}-0.3565$ & $\mathrm{O}-0.3564$ & $\mathrm{O}-0.3679$ & $\mathrm{O}-0.3677$ & $\mathrm{O} 0.0787$ & $\mathrm{O} 0.0688$ \\
& $\mathrm{H} 0.6782$ & $\mathrm{H} 0.6781$ & $\mathrm{H} 0.6739$ & $\mathrm{H} 0.6620$ & $\mathrm{H} 0.4478$ & $\mathrm{H} 0.4421$ \\
& $\mathrm{H} 0.6782$ & $\mathrm{H} 0.6777$ & $\mathrm{H} 0.6725$ & $\mathrm{H} 0.6143$ & $\mathrm{H} 0.3943$ & $\mathrm{H} 0.3599$ \\
& & $\mathrm{He} 0.0006$ & $\mathrm{Ne} 0.0215$ & $\mathrm{Ar} 0.0915$ & $\mathrm{Kr} 0.0791$ & $X \mathrm{O} 0.1292$ \\
\hline
\end{tabular}

${ }^{a} \mathrm{P}$ Excited state charge distribution of $\mathrm{H}_{2} \mathrm{O}^{+}-\mathrm{M}(\mathrm{He}, \mathrm{Ne}, \mathrm{Ar}, \mathrm{Kr}$ and $\mathrm{Xe})$ with the unit $\mathrm{e}^{-}$

${ }^{b}$ Represents $\mathrm{H}, \mathrm{O}, \mathrm{O}, \mathrm{M}(\mathrm{M}=\mathrm{He}, \mathrm{Ne}, \mathrm{Ar}, \mathrm{Kr}$ and $\mathrm{Xe})$ which marked on He only

gas elements and $\mathrm{H}_{2} \mathrm{O}^{+}$and their electronegativity and the result indicates that they are electropositive for giving unequal amount of electron cloud to $\mathrm{H}_{2} \mathrm{O}^{+}$. There is not so much change for the distribution of electrons in all cores in the system. The valence is the sum of their theoretical valence and their charge for all atoms. The Rydberg populations of $\mathrm{H}_{2} \mathrm{O}^{+}$is as follows: $0.006 \mathrm{e}^{-}$on $\mathrm{O}$ atom and $0.001 \mathrm{e}^{-}$on $\mathrm{H}$ atoms, while all of them are more than $0.007 \mathrm{e}^{-}$in $\mathrm{H}_{2} \mathrm{O}^{+}$-He in the other four on $\mathrm{O}$ atom and all of them are increased in all the complexes on $\mathrm{H}$ atoms from He to Xe. The Rydberg population of rare gas atoms in every complex is very little, therefore the electron state of the complexes is less active than that of $\mathrm{H}_{2} \mathrm{O}^{+}$.

The charge distribution of excited state of $\mathrm{H}_{2} \mathrm{O}^{+}-\mathrm{M}(\mathrm{He}$, $\mathrm{Ne}, \mathrm{Ar}, \mathrm{Kr}$ and $\mathrm{Xe}$ ) was shown in Table-10. Oxygen atoms have nearly equal negative charges between $-0.3679 \mathrm{e}^{-}$and $-0.3564 \mathrm{e}^{-}$in $\mathrm{H}_{2} \mathrm{O}^{+}-\mathrm{M}(\mathrm{He}, \mathrm{Ne}$ and $\mathrm{Ar})$ and oxygen atoms have been positive charged in $\mathrm{H}_{2} \mathrm{O}^{+}-\mathrm{M}(\mathrm{Kr}$ and $\mathrm{Xe})$ which are 0.0787 $\mathrm{e}^{-}$and $0.0688 \mathrm{e}^{-}$respectively. Hydrogen atoms have positive charges about $0.6143 \mathrm{e}^{-}$to $0.6777 \mathrm{e}^{-}$in $\mathrm{H}_{2} \mathrm{O}^{+}-\mathrm{M}(\mathrm{He}, \mathrm{Ne}$ and $\mathrm{Ar}$ ), which are $0.3943 \mathrm{e}^{-}$and $0.3599 \mathrm{e}^{-}$respectively in $\mathrm{H}_{2} \mathrm{O}^{+}-\mathrm{M}$ $(\mathrm{Kr}$ and $\mathrm{Xe}$ ). This reveals that $\mathrm{Kr}$ and $\mathrm{Xe}$ have stronger capacity to share positive charge from photoinduced holes. Noble gas atoms have smaller positive charges in $\mathrm{H}_{2} \mathrm{O}^{+}-\mathrm{M}(\mathrm{He}, \mathrm{Ne}, \mathrm{Ar}$, $\mathrm{Kr}$ and $\mathrm{Xe}$ ), which is the largest value $0.129 \mathrm{e}^{-}$on $\mathrm{Xe}$ and the smallest value $0.0006 \mathrm{e}^{-}$on $\mathrm{He}$.

Electronic transition: The qualitative molecular orbital representations of the highest occupied molecular orbitals (HOMOs) and the lowest unoccupied molecular orbitals (LUMOs) for $\mathrm{H}_{2} \mathrm{O}^{+}-\mathrm{M}(\mathrm{He}, \mathrm{Ne}, \mathrm{Ar}, \mathrm{Kr}$ and $\mathrm{Xe}$ ) are shown in Fig. 4. The energy gap of HOMOs and LUMOs is decline in

$\mathrm{H}_{2} \mathrm{O}^{+}-\mathrm{M}$ ( $\mathrm{He}, \mathrm{Ne}, \mathrm{Ar}, \mathrm{Kr}$ and $\mathrm{Xe}$ ) from up to down except that in $\mathrm{H}_{2} \mathrm{O}^{+}$-He which is smaller than those in others. Both the HOMOs and LUMOs have $\sigma$ characters. Each HOMO $\rightarrow$ LUMO transition corresponds to a $\sigma$ to $\sigma^{*}$ excited singlet state. The excitation of the electron from the HOMO to the LUMO leads the electronic density to flow mainly from noble gases to $\mathrm{H}_{2} \mathrm{O}^{+}$in $\mathrm{H}_{2} \mathrm{O}^{+}-\mathrm{M}(\mathrm{He}, \mathrm{Ne}, \mathrm{Ar}, \mathrm{Kr}$ and $\mathrm{Xe})$, which is increasing from up to down.

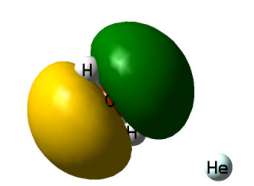

$\mathrm{H}_{2} \mathrm{O}^{+}$-He-TD-HOMO

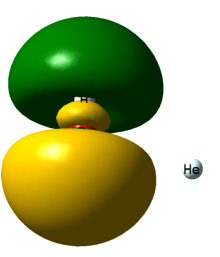

$\mathrm{H}_{2} \mathrm{O}^{+}$-He-TD-LUMO

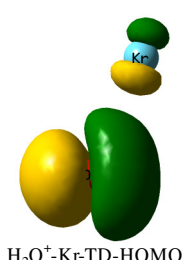

$\mathrm{H}_{2} \mathrm{O}^{+}$-Kr-TD-HOMO

Fig. 4. Frontier orbital diagrams of $\mathrm{H}_{2} \mathrm{O}^{+}-\mathrm{M}(\mathrm{He}, \mathrm{Ne}, \mathrm{Ar}, \mathrm{Kr}$ and $\mathrm{Xe}$ )

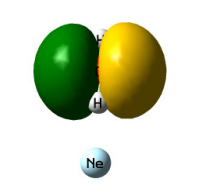

$\mathrm{H}_{2} \mathrm{O}^{+}$-Ne-TD-HOMO
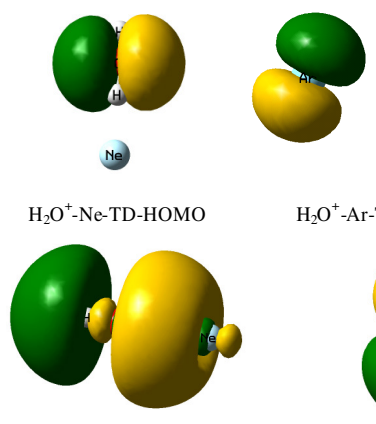

$\mathrm{H}_{2} \mathrm{O}^{+}$-Ar-TD-HOMO
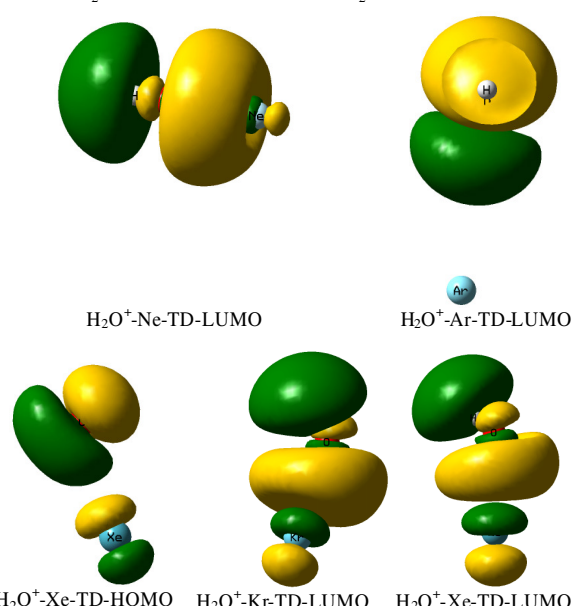
TABLE-11

GROUND STATE THERMOCHEMISTRY PARAMETERS OF $\mathrm{H}_{2} \mathrm{O}^{+}-\mathrm{M}(\mathrm{M}=\mathrm{He}, \mathrm{Ne}, \mathrm{Ar}, \mathrm{Kr}$ AND Xe)

\begin{tabular}{|c|c|c|c|c|c|c|c|c|c|c|}
\hline Parameter $^{\mathrm{a}}$ & \multicolumn{2}{|c|}{$\mathrm{H}_{2} \mathrm{O}-\mathrm{He}$} & \multicolumn{2}{|c|}{$\mathrm{H}_{2} \mathrm{O}-\mathrm{Ne}$} & \multicolumn{2}{|c|}{$\mathrm{H}_{2} \mathrm{O}-\mathrm{Ar}$} & \multicolumn{2}{|c|}{$\mathrm{H}_{2} \mathrm{O}-\mathrm{Kr}$} & \multicolumn{2}{|c|}{$\mathrm{H}_{2} \mathrm{O}-\mathrm{Xe}$} \\
\hline Freq $^{b}$ & 158.64 & 191.54 & 207.62 & 307.27 & 264.20 & 564.36 & 255.72 & 604.64 & 244.18 & 601.93 \\
\hline$\left(\mathrm{cm}^{-1}\right)$ & 279.82 & 1510.6 & 440.80 & 1523.0 & 694.30 & 1582.3 & 710.44 & 1611.1 & 661.08 & 1568.3 \\
\hline & 3345.9 & 3409.9 & 3372.2 & 3446.7 & 3487.4 & 3593.0 & 3548.1 & 3660.3 & 3626.5 & 3732.1 \\
\hline IR Inten $^{c}$ & 2.12 & 1.25 & 46.27 & 0.18 & 45.46 & 2.68 & 27.20 & 3.66 & 11.50 & 12.14 \\
\hline$(\mathrm{km} / \mathrm{mol})$ & 485.40 & 189.96 & 399.55 & 182.82 & 224.89 & 143.53 & 193.02 & 123.80 & 143.81 & 75.13 \\
\hline & 106.85 & 413.69 & 125.39 & 390.10 & 402.78 & 283.61 & 443.63 & 233.43 & 576.55 & 217.64 \\
\hline $\begin{array}{l}\mathrm{E}_{\text {electronic+zero-point }}^{\mathrm{d}} \\
\mathrm{kcal} / \mathrm{mol}\end{array}$ & \multicolumn{2}{|c|}{-49481.05} & \multicolumn{2}{|c|}{-128573.66} & \multicolumn{2}{|c|}{-378709.82} & \multicolumn{2}{|c|}{-1775683.87} & \multicolumn{2}{|c|}{-57406.50} \\
\hline $\mathrm{E}_{\text {electronictthermal }}^{\mathrm{e}} \mathrm{kcal} / \mathrm{mol}$ & \multicolumn{2}{|c|}{-49475.40} & \multicolumn{2}{|c|}{-128568.01} & \multicolumn{2}{|c|}{-378705.42} & \multicolumn{2}{|c|}{-1775679.48} & \multicolumn{2}{|c|}{-57402.10} \\
\hline $\mathrm{H}_{\text {electronic+thermal }}^{\mathrm{f}} \mathrm{kcal} / \mathrm{mol}$ & \multicolumn{2}{|c|}{-49474.14} & \multicolumn{2}{|c|}{-128566.76} & \multicolumn{2}{|c|}{-378704.17} & \multicolumn{2}{|c|}{-1775678.85} & \multicolumn{2}{|c|}{-57400.85} \\
\hline $\mathrm{G}_{\text {electronictthermal }}^{\mathrm{g}} \mathrm{kcal} / \mathrm{mol}$ & \multicolumn{2}{|c|}{-49510.54} & \multicolumn{2}{|c|}{-128604.41} & \multicolumn{2}{|c|}{-378741.82} & \multicolumn{2}{|c|}{-1775717.13} & \multicolumn{2}{|c|}{-57440.38} \\
\hline
\end{tabular}

${ }^{a}$ Parameter refers to thermochemistry parameters of $\mathrm{H}_{2} \mathrm{O}^{+}-\mathrm{M}\left(\mathrm{M}=\mathrm{He}, \mathrm{Ne}, \mathrm{Ar}, \mathrm{Kr}\right.$ and Xe); ${ }^{\text {b}}$ Freq refers to the infrared absorption frequencies. ${ }^{\mathrm{c}} \mathrm{IR}$ Inten refers to the infrared absorption intensity; ${ }^{\mathrm{d}} \mathrm{E}$ electronic and zero-point refers to the sum of electronic and zero-point energy of $\mathrm{H}_{2} \mathrm{O}^{+}-\mathrm{M}_{\text {. }}$ ${ }^{\mathrm{e}} \mathrm{E}$ electronic and thermal (A.U) refers to the sum of electronic and thermal energy of $\mathrm{H}_{2} \mathrm{O}^{+}-\mathrm{M}$; ${ }^{\mathrm{f}} \mathrm{H}$ electronic and thermal (A.U) refers to the sum of electronic and thermal enthalpy of $\mathrm{H}_{2} \mathrm{O}^{+}-\mathrm{M}$; ${ }^{\mathrm{g}} \mathrm{G}$ electronic and thermal (A.U) refers to the sum of electronic and thermal free energy $\mathrm{H}_{2} \mathrm{O}^{+}-\mathrm{M}$

Energy parameters of $\mathrm{H}_{2} \mathrm{O}^{+}-\mathrm{M}(\mathrm{He}, \mathrm{Ne}, \mathrm{Ar}, \mathrm{Kr}$ and Xe): Ground state thermochemistry parameters of $\mathrm{H}_{2} \mathrm{O}^{+}-\mathrm{M}$ $(\mathrm{He}, \mathrm{Ne}, \mathrm{Ar}, \mathrm{Kr}$ and $\mathrm{Xe}$ ) are fluctuated with the different element in the rare gas group as shown in Table-11. The sum of electronic and zero-point energy ( $\mathrm{E}_{\text {electronic+zero-point }} \mathrm{kcal} / \mathrm{mol}$ ), the sum of electronic and thermal energy ( $E_{\text {electronictthermal }} \mathrm{kcal} /$ $\mathrm{mol})$, the sum of electronic and thermal enthalpy $\left(\mathrm{H}_{\text {electronictthermal }}\right.$ $\mathrm{kcal} / \mathrm{mol}$ ) and the sum of electronic and thermal free energy $\left(\mathrm{G}_{\text {electronictthermal }} \mathrm{kcal} / \mathrm{mol}\right)$ are increased from $\mathrm{He}$ to $\mathrm{Kr}$ and which are reduced as to $\mathrm{H}_{2} \mathrm{O}^{+}$-Xe and which of $\mathrm{H}_{2} \mathrm{O}^{+}$-Xe are higher than that of $\mathrm{H}_{2} \mathrm{O}^{+}$-Ar. As to the same element, the highest value among the four is the sum of electronic and thermal free energy $\left(\mathrm{G}_{\text {electronictthermal }} \mathrm{kcal} / \mathrm{mol}\right)$ and the lowest value is the sum of electronic and thermal enthalpy $\left(\mathrm{H}_{\text {electronictthermal }} \mathrm{kcal} / \mathrm{mol}\right)$. The highest (lowest value of entropy among the five complexes is in $\mathrm{H}_{2} \mathrm{O}^{+}-\mathrm{He}$ ) value of entropy among the five complexes is in $\mathrm{H}_{2} \mathrm{O}^{+}$-Xe according the following formula: $\mathrm{S}=\mathrm{H}-\mathrm{G} / \mathrm{T}$, which is consistent with the geometrical parameters and the relative atomic mass of $\mathrm{He}, \mathrm{Ne}, \mathrm{Ar}, \mathrm{Kr}$ and $\mathrm{Xe}$.

It is because of the increasing of the atomic number and the diminishing interaction between the rare gas group elements and $\mathrm{H}_{2} \mathrm{O}^{+}$. There were three infrared absorption frequencies of $\mathrm{H}_{2} \mathrm{O}^{+}$which were $1505.15,3337.80$ and 3397.98 $\mathrm{cm}^{-1}$. The wagging vibration of $\mathrm{H}-\mathrm{O}$ bond is at $1505.15 \mathrm{~cm}^{-1}$ and the symmetrical stretching vibration of $\mathrm{H}-\mathrm{O}$ bond is at $3337.80 \mathrm{~cm}^{-1}$ and the asymmetrical stretching vibration of $\mathrm{H}-\mathrm{O}$ is at $3397.39 \mathrm{~cm}^{-1}$. In $\mathrm{H}_{2} \mathrm{O}^{+}-\mathrm{M}$ ( $\mathrm{He}, \mathrm{Ne}, \mathrm{Ar}, \mathrm{Kr}$ and $\mathrm{Xe}$ ) there were 6 infrared absorption frequencies which were the stretching vibration of $\mathrm{O}-\mathrm{M}(\mathrm{M}=\mathrm{He}, \mathrm{Ne} \mathrm{Ar}, \mathrm{Kr}$ and $\mathrm{Xe})$, the asymmetrical stretching vibration of $\mathrm{H}-\mathrm{M}$ bond, the symmetrical stretching vibration of $\mathrm{H}-\mathrm{M}$ bond, the wagging vibration of $\mathrm{H}-\mathrm{O}$ bond, the symmetrical stretching vibration of $\mathrm{H}-\mathrm{O}$ bond and the asymmetrical stretching vibration of $\mathrm{H}-\mathrm{O}$, which were one to one correspondence to the increasing frequencies among the 6 ones. The intensity of the latter 4 frequencies are stronger than that of the foregoing 2. The specific frequencies are different in $\mathrm{H}_{2} \mathrm{O}^{+}-\mathrm{M}(\mathrm{He}, \mathrm{Ne}, \mathrm{Ar}, \mathrm{Kr}$ and $\mathrm{Xe}$ ) because of the different strength of the O-M bond and symmetry of the complexes.

The excited state energy parameters of $\mathrm{H}_{2} \mathrm{O}^{+}-\mathrm{M}(\mathrm{He}, \mathrm{Ne}$, $\mathrm{Ar}, \mathrm{Kr}$ and $\mathrm{Xe}$ ) including transition energy, amplitude and maximum absorption wavelength were shown in Table-6. The transition energy values of $\mathrm{H}_{2} \mathrm{O}^{+}-\mathrm{M}(\mathrm{He}, \mathrm{Ne}$ and $\mathrm{Ar}$ ) are between 11 and $8 \mathrm{eV}$, while that of $\mathrm{H}_{2} \mathrm{O}^{+}-\mathrm{Kr}$ is $4.13 \mathrm{eV}$ and the transition energy of $\mathrm{H}_{2} \mathrm{O}^{+}$-Xe is $2.45 \mathrm{eV}$ which are smaller than that of pure $\mathrm{TiO}_{2}$ acted as photocatalyst in the reaction system, therefore $\mathrm{Xe}$ is favourable to the photoreactivation at excited of $\mathrm{H}_{2} \mathrm{O}$ in the reaction system. Amplitudes of $\mathrm{H}_{2} \mathrm{O}^{+}$$\mathrm{Xe}$ is maximum ( $\mathrm{f}=0.0768)$ among the five complexes and that of $\mathrm{H}_{2} \mathrm{O}^{+}-\mathrm{Kr}$ takes the second place (0.0405). The maximum absorption wavelength of $\mathrm{H}_{2} \mathrm{O}^{+}-\mathrm{Xe}$ is at $506.06 \mathrm{~nm}$ and that of $\mathrm{H}_{2} \mathrm{O}^{+}-\mathrm{Kr}$ is at $300.06 \mathrm{~nm}$, which are consistent to their larger amplitude and smaller transition energy, so they are beneficial to the photoreaction. While other complexes absorption peak are under $150 \mathrm{~nm}$.

\section{Conclusion}

The $\mathrm{CO}_{2}$ molecule captured a photo-induced electron to become $\mathrm{CO}_{2}{ }^{--}$and it combined with boron group elements to form complexes. The complexes formed by $\mathrm{CO}_{2}{ }^{--}$with boron group elements was expressed as $\mathrm{CO}_{2}{ }^{--}-\mathrm{M}(\mathrm{B}, \mathrm{Al}, \mathrm{Ga}$, In and $\mathrm{Tl}$ ); $\mathrm{H}_{2} \mathrm{O}$ molecule captured a photo-induced hole to become $\mathrm{H}_{2} \mathrm{O}^{+}$and it combined with the rare gas elements to form complexes $\mathrm{H}_{2} \mathrm{O}^{+}-\mathrm{M}$ ( $\mathrm{He}, \mathrm{Ne}, \mathrm{Ar}, \mathrm{Kr}$ and $\mathrm{Xe}$ ). The different effects of noble gas and boron group elements have been calculated at MP2 level. Our results revealed that the ground state structural parameters, the charge distribution and the thermochemistry parameters were changed according to the order from up to down in the same group. It indicate that electron-defect atom might maintain the structure $\mathrm{CO}_{2}{ }^{--}$of like $\mathrm{CO}_{3}{ }^{2-}$, which is convenient for appropriate radicals ${ }^{25}$ reacting with $\mathrm{CO}_{2}{ }^{--}$to form the aim product or its precursor, therefore for the electron-defect atom is advantageous to the reaction herein. It is interesting that all complexes have shorter bond length than that of $\mathrm{H}_{2} \mathrm{O}^{+}$and the rare gas elements tend to inert $\mathrm{H}_{2} \mathrm{O}^{+}$to back to the structure of $\mathrm{H}_{2} \mathrm{O}$. The excited state parameters showed that $\mathrm{Ga}, \mathrm{Kr}$ and $\mathrm{Xe}$ are beneficial to the photoreduction of $\mathrm{CO}_{2}$ with $\mathrm{H}_{2} \mathrm{O}$. The other interaction between reactants and intermediate species will be studied in the future work.

\section{ACKNOWLEDGEMENTS}

This work was supported by Youth Science Foundation of Heilongjiang Province, P.R. China (QC2010121). 


\section{REFERENCES}

1. M. Anpo and K. Chiba, J. Mol. Catal., 74, 207 (1992).

2. H. Yamashita, H. Nishiguchi, N. Kamada, M. Anpo, Y. Teraoka, H. Hatano, S. Ehara, K. Kikui, L. Palumisano, A. Sclafani, M. Schiavello and M.A. Fox, Res. Chem. Intermed., 20, 815 (1994).

3. H. Yamashita, N. Kamada, H. He, K. Tanaka, S. Ehara and M. Anpo, Chem. Lett., 23, 855 (1994).

4. M. Anpo, H. Yamashita, Y. Ichihashi and S. Ehara, J. Electroanal. Chem., 396, 21 (1995).

5. N. Sasirekha, S.J.S. Basha and K. Shanthi, Appl. Catal. B: Environ., 62, 169 (2006)

6. M. Ashokkumar, Int. J. Hydrogen Energy, 23, 427 (1998).

7. J. Bard A and M.A. Fox, Acc. Chem. Res., 28, 141 (1995).

8. T. Takata, A. Tanaka, M. Hara, J.N. Kondo and K. Domen, Catal. Today, 44, 17 (1998).

9. M.A. Gondal, A. Hameed, Z.H. Yamani et al., Chem. Phys. Lett., 385 , 111 (2004).

10. A. Hameed and M.A. Gondal, J. Mol. Catal., 219, 109 (2004).

11. M. Yagi and M. Kaneko, Chem. Rev., 101, 21 (2001).

12. A.H. Yahaya, M.A. Gondal and A. Hameed, Chem. Phys. Lett., 400, 206 (2004)

13. J.C. Sin, S.M. Lam, A.R. Mohamed and K.T. Lee, Int. J. Photoenergy, 2012, 1 (2012)

14. M. Head-Gordon, J.A. Pople and M.J. Frisch, Chem. Phys. Lett., 153, 503 (1988).

15. M.J. Frisch, M. Head-Gordon and J.A. Pople, Chem. Phys. Lett., 166, 275 (1990).

16. M.J. Frisch, M. Head-Gordon and J.A. Pople, Chem. Phys. Lett., 166, 281 (1990).
17. M. Head-Gordon and T. Head-Gordon, Chem. Phys. Lett., 220, 122 (1994).

18. P.J. Hay and W.R. Wadt, J. Chem. Phys., 82, 270 (1985); P.J. Hay and W.R. Wadt, J. Chem. Phys., 82, 284 (1985); P.J. Hay and W.R. Wadt, J. Chem. Phys., 82, 299 (1985).

19. R. Krishnan, J.S. Binkley, R. Seeger and J.A. Pople, J. Chem. Phys., 72, 650 (1980).

20. A.D. McLean and G.S. Chandler, J. Chem. Phys., 72, 5639 (1980).

21. L.A. Curtiss, M.P. McGrath, J.-P. Blandeau, N.E. Davis, R.C. Binning, and L. Radom, J. Chem. Phys., 103, 6104 (1995).

22. M. J. Frisch, G. W. Trucks, H. B. Schlegel, G. E. Scuseria, M.A. Robb, J.R. Cheeseman, G. Scalmani, V. Barone, B. Mennucci, G.A. Petersson, H. Nakatsuji, M. Caricato, X. Li, H.P. Hratchian, A.F. Izmaylov, J. Bloino, G. Zheng, J.L. Sonnenberg, M. Hada, M. Ehara, K. Toyota, R. Fukuda, J. Hasegawa, M. Ishida, T. Nakajima, Y. Honda, O. Kitao, H. Nakai, T. Vreven, J.A. Montgomery, Jr., J.E. Peralta, F. Ogliaro, M. Bearpark, J.J. Heyd, E. Brothers, K.N. Kudin, V.N. Staroverov, R. Kobayashi, J. Normand, K. Raghavachari, A. Rendell, J.C. Burant, S.S. Iyengar, J. Tomasi, M. Cossi, N. Rega, J.M. Millam, M. Klene, J.E. Knox, J.B. Cross, V. Bakken, C. Adamo, J. Jaramillo, R. Gomperts, R.E. Stratmann, O. Yazyev, A.J. Austin, R. Cammi, C. Pomelli, J.W. Ochterski, R.L. Martin, K. Morokuma, V.G. Zakrzewski, G.A. Voth, P. Salvador, J.J. Dannenberg, S. Dapprich, A. D. Daniels, O. Farkas, J.B. Foresman, J.V. Ortiz, J. Cioslowski and D.J. Fox, Gaussian 09, Revision A.1, Wallingford CT (2009).

23. V.P. Indrakanti, J.D. Kubicki and H.H. Schobert, Energy Fuels, 22, 2611 (2008).

24. S. Liang, S. Zhu, J. Zhu, Y. Chen, Y. Zhang and L. Wu, Phys. Chem. Chem. Phys., 14, 1212 (2012).

25. Z.M.O. Rzayev, Int. Rev. Chem. Eng., 3, 153 (2011). 